Cad. Benjaminianos, Belo Horizonte, v. 15, n. 1, p. 281-322, 2019

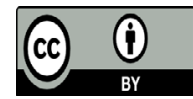

\title{
Mutações materialistas da Bilderverbot
}

Rebecca Comay

\author{
Tradução Alessandra A. Martins Parente \\ Universidade de São Paulo (USP), São Paulo, São Paulo / Brasil \\ aamparente@gmail.com
}

\begin{abstract}
Por que somente os idealistas devem ter permissão
para andar na corda bamba, enquanto aos materialistas andar na corda bamba é proibido?

Walter Benjamin, citado por Gershom Scholem
\end{abstract}

\section{Secularizações}

Nenhum idealista, mas apenas uma libertação materialista do mito.

Benjamin, 'Karl Kraus'

O que poderia estar em ação na versão marxista da proibição teológica de imagens? Em sua Dialética Negativa, Theodor Adorno vincula explicitamente a crítica já familiar da representação (mediação, midiatização, sociedade do espetáculo) ao imperativo secular de "apreender o próprio objeto" [die Sache zu begreifen] em sua verdade corporal. Tal 'apreensão' pareceria re-modular o anseio teológico por redenção junto a linhas decididamente a-teológicas:

[...] só sem imagens seria possível pensar o objeto plenamente. Uma tal ausência de imagens converge com a interdição teológica às imagens. $\mathrm{O}$ materialismo a seculariza na medida em que não 
permite que se pinte a utopia positivamente; esse é o teor de sua negatividade. Ele está de acordo com a teologia lá onde é maximamente materialista. Sua nostalgia seria a ressurreição na carne; para o idealismo, para o reino do espírito absoluto, essa nostalgia é totalmente estranha. (Adorno, 1966, p. 205 apud Comay, 2005, p. 32/ Adorno (trad. Casanova), 1966/2009, p. 176) ${ }^{1}$

Sugiro usar essa surpreendente passagem - uma formulação que parece anunciar nada menos que o recuo do ideal ascético sobre si - como ponto de partida para reexaminar o debate bem ensaiado entre Adorno e Benjamin.

O que devemos pensar sobre esse casamento profano entre teologia e materialismo? De qualquer maneira, será mais do que uma questão de encontrar paralelos vagos ou empréstimos sub-reptícios (uma fácil compreensão do marxismo como "credo" ou "dogma" milenar, aceno familiar para o retorno à história judaica): uma questão não de compatibilidade nem de cumplicidade, mas sim de um "acordo" forjado precisamente onde a antítese parece mais intratável. Pois, de acordo com tal refutação da proibição monoteísta, a aparente mortificação dos sentidos viria a sinalizar não a recompensa familiar da realização super-sensual - a passagem sublime da cegueira física para a percepção espiritual (Édipo, Tirésias) - mas a vindicação do próprio corpo no ponto exato de sua desfiguração mais irreparável. Em seu limite, portanto, dizse que o materialismo absorve ou reinscreve a teologia precisamente ao falar de uma restituição além de toda compensação idealizante e, nesse sentido, intransigentemente desoladora.

Como o imperativo iconoclasta se conecta aqui à promessa da ressurreição? E como cada um ou ambos, juntos ou separados, resistiriam à tentação do outro mundo? Se a redenção do corpo sofredor exclui qualquer representação ou mediação de sua singularidade, isso só poderia implicar uma espécie de retorno fora da economia restrita de uma salvação baseada na troca compensatória de abstrações comensuráveis. Implicaria, assim, algo além da metamorfose espiritual de um corpo elevado à imortalidade, racionalidade e apatheia [apatia] divinas. Em suma, indicaria a persistência da matéria em sua alteridade totalmente irreconciliável.

\footnotetext{
${ }^{1}$ As traduções existentes e publicadas no português foram consultadas e adotadas para citações mais extensas.
} 
Tal redenção sugeriria, portanto, algo além da theiosis [divinização] do indivíduo aperfeiçoado, formado à imagem da divindade incorruptível. Essa última noção inevitavelmente substituiria o ídolo banido pela imagem essencializada de um Deus incorpóreo. O insight espiritual resgataria a cegueira da visão corpórea. "Imagem do invisível" (Colossenses 1:15), a aparição de Cristo apresentaria a possibilidade de uma visão em última análise purificada do imediatismo sensual e, portanto, a própria promessa de vitória do espírito sobre a matéria morta. A transfiguração paulina do grão de trigo - 'semeado em humilhação, ressuscitado em glória' (1 Coríntios 15:44) - pressupõe a oikonomia divina de uma redenção mimetologicamente assegurada pela figura de Cristo como imago Dei e assim garantida à humanidade precisamente como portadora do "selo" "chancela" ou impressão celestial.

$\mathrm{O}$ que significaria articular o Bilderverbot sem o recurso à mimetologia sublimada do idealismo? E como seria uma ressurreição não-transfiguradora? Seria tentador, mas equivocado aqui, confrontar rapidamente uma escatologia "cristã" com uma "judaica" - os ossos secos de Ezequiel contra o corpo espiritual de São Paulo, o pote remendado de Sinédrio contra a estátua refeita de Agostinho - a fim de marcar os termos essenciais da oposição. O desafio filosófico de pensar uma restituição não reconciliadora permanece, no entanto, urgente.

"Redenção", como Benjamin escreve (a alusão está aqui em Kafka), "não é prêmio (ou recompensa) pela existência, mas a última saída" [die Erlosung ist keine Pramie auf das Dasein, sondern die letzte Ausflucht] (GS 2.2:423/SW 2:804 apud Comay, 2005, p. 33-34). Em jogo aqui não é o retorno da comensuração espiritual, mas, ao contrário, uma ruptura ainda mais radical pressuposta em uma diferença imperceptível um "ligeiro ajuste" [eine Geringes zurechtstellen] (GS 2.2:432/SW 2:811 apud Comay, 2005, p. 34)) - entre esse mundo e o seguinte. Qualquer que seja a "fraqueza" do poder messiânico ( $G S$ 1.2:694/SW 4:390 apud Comay, 2005, p. 34) - o anjo da história não pode demorar, não pode despertar os mortos, não pode tornar inteiro o que foi destruído, e assim por diante ( $G S$ 1.2:697-8/SW 4:392 apud Comay, 2005, p. 34) - a própria identificação do messiânico com o domínio da transitoriedade ou "decadente" (GS 2.1:204 apud Comay, 2005, p. 34) (a insinuação nietzschiana é inconfundível) sugeriria que a redenção não pode ser pensada além ou separadamente do eterno retorno de remanescentes ou de restos corpóreos, sem compensação totalizante. Se os mortos não podem 
ser ressuscitados isso é, sem dúvida, pela mesma razão que a eles não pode ser dito que morressem apropriadamente ou seguramente: "Mesmo os mortos não estão a salvo do inimigo se ele vencer" (GS 1.2:695/SW 4:391 apud Comay, 2005, p. 34). Nosso rendezvouz permanente ou encontro marcado com "gerações passadas" (GS 1.2:694/SW 4:390 apud Comay, 2005, p. 34) indica precisamente a tenacidade da matéria morta como aquela que assombra a plenitude do presente vivo. "Sobreviver" [Überleben] torna-se assim a obsolescência perpétua que de uma só vez define e subverte a tradição.

Adorno evocará Kafka de maneira semelhante (em Prismas). Se a teoria da 'morte malsucedida' (Odradek, Gracchus) "é a única promessa de imortalidade... permiti[da] a sobreviver à proibição das imagens", a própria possibilidade de redenção dependeria precisamente do fato de que inevitavelmente chega tarde demais. Assim, a famosa litania de oportunidades perdidas: o fracasso da filosofia que se negou à pratica (Dialética Negativa), a incapacidade da burguesia de "encontrar um sucessor" (Prismas, 273/260 apud Comay, 2005, p. 34), a necrologia da arte anunciada na Teoria Estética. Essa longevidade culpada - o outro lado do diferimento kantiano - atesta precisamente um imperativo ainda mais urgente de ser anunciado tarde demais. "A ressurreição dos mortos teria que ocorrer nas próprias covas" (Prismas, p. 273/260 apud Comay, 2005, p. 34).

\section{Dilema de Benjamin}

No prefácio notoriamente hermético de seu Trauerspielbuch, Benjamin identifica o regime de visão - Schau, Anschauung, a projeção fenomenológica de horizontes - como a operação aquisitiva ou "possessiva" do sujeito em busca de confirmação naquilo que sabe (GS 1.1:215/OT, p. 35 apud Comay, 2005, p. 34). É dito, sabe-se, que a verdade resiste a isso. A verdade não-intencional e não-relacional, de acordo com a fórmula de Benjamin (que, a esse respeito, se assemelha à de Levinas), "não é um desvelamento [Enthüllung] que destrói o mistério, mas uma revelação [Offenbarung] que faz justiça" (GS 1.1:211/OT, p. 31 apud Comay, 2005, p. 34). Tornou-se um tanto convencional ler aqui uma continuação e radicalização de certa tendência dentro do judaísmo ortodoxo e heterodoxo em direção a uma atenuação de qualquer conceito positivo de revelação: a ênfase rabínica na auralidade (a "voz do Sinai"), 
a ênfase cabalística no nome divino. Em resumo: o excesso hermenêutico da interpretação sobre o significado e, portanto, a desmistificação de toda revelação autoritária.

A predominância da linguagem sobre a visão, de acordo com uma convenção, sugeriria um certo privilégio do Simbólico sobre o Imaginário e, portanto, a exclusão de toda efusão de fantasia. A visualização convida à identificação e, assim, inevitavelmente, ao espectro da confusão idólatra: a heterogeneidade do absoluto requer uma denúncia da 'bela aparência' [schöner Schein] como a renúncia da ordem apropriativa do Mesmo.

Benjamin falará, de fato, de sacrifício. A beleza é para ser imolada - mas simultaneamente busca "refúgio" - no "altar da verdade" (GS 1.1:211/OT, p. 31 apud Comay, 2005, p. 35). A prioridade da 'verdade' à 'beleza' neste contexto (Hermann Cohen nunca está distante) provocará em outro lugar uma invocação prolongada de um certo sublime (GS 1.1:181/SW 1:340 apud Comay, 2005, p. 35): Kant, Novalis, a familiar "fábula" da "imagem velada" de Ísis, cuja inauguração é dito ser fatal - destruidora, até mesmo castradora [zusammenbrechend] - para o investigador. (GS 1.1:216/OT, p. 37 apud Comay, 2005, p. 35).

A proibição referida aqui não é de forma alguma simples. Se Benjamin invocará um tropo suficientemente tradicional da verdadecomo-mulher - objeto inacessível, invisível, inexpressível de um desejo impossível - isto não é para restabelecer os cultos de mistério sob a rubrica de iconoclastia. Isso seria apenas reduzir o Bilderverbot a um simples esoterismo - "alguma crueldade enigmática em significado real" (GS 1.1:216/OT, p. 36 apud Comay, 2005, p. 35) -, assim, finalmente, reificar o objeto perdido como simples positividade.

Para a exposição da verdade aqui - o objeto nem "velado" [verhüllt] nem "desvelado" [enthüllt], mas sim o próprio objeto em seu "sendo-velado" (GS 1.1:195/ SW 1:351 apud Comay, 2005, p. 35) implica simultaneamente uma "rendição" (GS 1.1:184/SW 1:342 apud Comay, 2005, p. 35) e uma "intensificação de aparência [Schein] em uma forma final e mais extrema" (GS 1.1:186/SW 1:344 apud Comay, 2005 , p. 35). A perda na mediação representacional ou intencional envolveria um ganho correspondente na intensidade "presentacional" [darstellende] em que o que é abandonado é elevado, e isso de acordo com a devida medida de sua própria negação. O próprio sacrifício da estética - Benjamin fala em um contexto relacionado ao "sacrifício" de Proust do caráter, enredo, jogo da imaginação, e assim por diante ( $G S$ 
2.1:314/SW 2:239 apud Comay, 2005, p. 35) - seria acompanhado e, na verdade, contrabalanceado pela expansão de uma certa "esfera da imagem" [Bildraum] em que a própria linguagem, como acontecerá, vem à tona.

O núcleo central da disputa entre Benjamin e Adorno reside justamente aqui. Pois um sacrifício tão "sublime" não pareceria envolver uma lógica compensatória familiar, pelo menos desde Kant e Hegel: menos é mais, qui perd gagne, a lógica escravista da autonegação recuperativa? Como resgatar tal sacrifício do cálculo racionalista identificado por Adorno e Horkheimer como a dialética de Aufklarung - o círculo mítico de renúncia e recompensa? O que impedirá que a versão de Benjamin da "salvação dos fenômenos" se reverta em uma simples legitimação do existente?

Essa será precisamente a pergunta final de Adorno a Benjamin.

\section{Antes da lei}

Ao quebrar uma estátua, arrisca-se a tornar-se uma estátua ... Jean Cocteau, Le sang d'un poete

Como pode uma proibição contra imagens ser enunciada? Não há algo profundamente contraditório sobre a própria representação da lei que proíbe representações do absoluto? A lei não iria inevitavelmente transgredir-se em seu próprio pronunciamento? Não estimularia, de fato, a própria iconofilia que ela proíbe - isso de acordo com a imbricação irredutível da lei com desejo, proscrição com prazer -e, portanto, enfraqueceria a si-mesma em sua própria enunciação?

A questão aqui envolve um pouco mais do que a concomitante ligação dupla em toda lei em sua força e promessa auto-universalizantes. Hegel (1977 apud Comay 2005) já tinha identificado esse problema inicial, um problema lógico, em seu capítulo sobre "Força e Entendimento": esse é o paradoxo de uma lei tornada vazia pela sua repetitividade formal e, portanto, pelo poder vinculativo. Isso envolve também mais do que a autocontradição performativa de um pronunciamento que se deslegitima a si mesmo precisamente em virtude da sua própria legalidade. Pronunciar o Bilderverbot é em si assumir autoridade legislativa - assim, identificar-se 
com a origem da lei mesmo que apenas para falar disso e em seu nome nesse sentido, cometendo autoidolatria precisamente para restringi-la ou limitá-la, contaminando transcendência no próprio esforço de proteger sua pureza, assumindo a culpa essencial que ela impediria. Siga-me/ não me siga... não é a Bilderverbot a este respeito, a mais auto transgressiva de todas as leis? Invocada para ser violada - não é verdade que ela justamente exemplifica a impossibilidade última da lei como tal? Há, no entanto, mais de uma maneira de responder a tal impossibilidade.

Em questão, aqui, não está apenas o familiar ponto de vista psicanalítico (a respeito do retorno do reprimido como sintoma neurótico), nem só o foucaultiano (sobre a produtividade positiva da lei em sua própria negatividade). Alguém deve observar com igual convicção - este será o meu argumento essencial - que se toda a proibição incita e requer uma transgressão correspondente, é também inversamente o caso que, através da sua auto-infração aparente, a lei só nos liga mais estreitamente (embora para aquilo que permanece indeterminado). Neste caso a incapacidade da lei em autorizar a si mesma talvez ateste igualmente a uma proibição ainda mais profunda, talvez em última análise inescrutável - mas talvez igualmente à alegação de um desejo indescritível.

Talvez algo mais do que a reciprocidade dialética esteja em ação em tal quiasma da lei e da transgressão. Talvez neste duplamente contaminante movimento de regulação auto desreguladora e desregulação auto reguladora outra relação tanto com a lei quanto com a imagem pode começar a anunciar-se.

Ambiguidade é a aparência imagética da dialética, a lei da dialética da paralisada. Benjamin, 'Paris - a capital do século XIX

Desde Kant, se não de fato desde Longinus, tornou-se habitual comentar sobre a natureza "meta-sublime" da própria lei que anuncia a incomensurabilidade essencial entre lei e manifestação - o Segundo Mandamento aqui considerado não apenas como a declaração paradigmática sobre o sublime mas também o próprio paradigma de uma "declaração sublime" (Kant, 1951, §29 apud Comay, 2005, p. 37) - 
sugerindo a suprema aporia de uma lei que se exemplifica precisamente ao pronunciar a impossibilidade de cada exemplo. Assim, a advertência bíblica referente a toda possível (inevitável) retificação da lei. A quebra e reescrita de Moisés das tábuas no Sinai expressa precisamente a necessidade da iconoclastia de segundo grau importante para sustentar a lei, mitigando sua evidência eidética, marcando assim suas origens em um evento anterior de auto apagamento e, portanto, sua inscrição irredutível dentro do domínio da história. $O$ conjunto de substituição - não mais identificado como "obra de Deus" (Êxodo 32:16), mas inexoravelmente marcado como substituto ou simulacro, escrita em vez de "gravura" como tal significa a impossibilidade de qualquer relação imediata com o original. Isso anuncia a duplicação originária da lei como imbricação permanente da lei e da interpretação. "É de uma palavra já destruída que o homem aprende a demanda que deve falar com ele" (Blanchot, 1985, p. 49 apud Comay, 2005, p. 37).

Mas se a lei assim incorpora sua própria infração exatamente como a condição de sua própria articulação, ela afirma igualmente que toda adesão é marcada por uma violação correspondente. A destruição das tábuas antecipa a pulverização do bezerro de ouro, que, por sua vez, em sua agressividade literalizante, apenas confirma o poder carismático do ídolo. A acusação de idolatria nesse sentido tipicamente pressupõe (como Hegel aponta em sua análise da cruzada do Iluminismo contra a superstição) uma suposição "não muito esclarecida" (Hegel, 1977, p. 344 apud Comay, 2005, p. 37) sobre a relação entre o ser finito e o absoluto, e por isso mistifica o próprio ato de desmistificação como uma "nova serpente de sabedoria elevada ao alto para adoração". (Hegel, 1977, p. 344 apud Comay, 2005, p. 37)

E assim por diante. O ponto não é simplesmente formal ou lógico, nem a questão é estranhamente teológica. Ele expõe um risco que afeta todas as políticas radicais. Pois a própria renúncia das imagens ameaça precisamente determinar o futuro como uma tabula rasa ou uma lousa em branco receptiva às projeções arbitrárias dos dias atuais. "Tempo vazio homogêneo" seria reintegrado. A velha "concepção geométrica do futuro" - a expressão é de Bataille - seria restabelecida. Mesmo deixando de lado os paradoxos familiares que acompanham a noção de utopia determinada essencialmente como a própria ausência de determinação - a imagem convencional de um mundo sem imagens -, o perigo da abstração permanece inelutável. 
Como evitar uma recaída numa negatividade indeterminada e, portanto, no imediatismo? Toda Bilderverbot não pressuporia a familiar série platônica de bifurcações - essência / aparência, original / cópia, verdade / ideologia - e, portanto, um prolongamento do ideal ascético?

Muito parece estar em jogo aqui.

Politicamente: como resistir a reificar a negatividade em si mesma como consolo justamente do que está sendo negado?

Teologicamente: como resistir à invocação da teologia negativa como anverso simétrico do fundamentalismo dogmático?

Ainda não poderemos nomear a lei sob a qual estamos.

Benjamin, Gedanken über Gerhart Hauptmanns Festspiel

Há, poderíamos dizer, articulações míticas e não-míticas do dilema. Ou seja: o inevitável círculo de lei-e-transgressão pode ser introduzido em uma variedade de formas. Se, para introduzir os termos de Benjamins, o regime do destino é definido pelo círculo compulsivo de culpa-retribuição-culpa que transforma o "contexto de culpa dos vivos" (GS 1.1:138/SW 1:307 apud Comay, 2005, p. 38) no pesadelo de um "interminável julgamento" (GS 2.2:412/SW 2:796 apud Comay, 2005 , p. 38) - dos ciclos trágicos do drama grego à vertigem prolongada da Processo de Kafka - tal regime também aporta uma "ambiguidade" essencial [Zweideutigkeit] (GS 2.1: 1997 SW 1: 249 apud Comay, 2005, p. 38) que pode ocultar recursos inesperados.

De acordo com os termos da "Crítica da Violência", a origem mítica da lei (cf. GS 2.1:154/SW 1:71-2 apud Comay, 2005, p. 38) sugere "a definitiva indecidibilidade de todos os problemas legais" (GS 2.1:196/SW 1:247 apud Comay, 2005, p. 38) e, eventualmente, aponta para a incapacidade da própria lei para determinar a prática. Assim, o "novo advogado" de Kafka não mais pratica, mas apenas "estuda" a lei (GS 2.2:437/SW 2:815 apud Comay, 2005, p. 38) - um impasse que acabará por receber sua formulação mais nítida na noção de Kafka de um julgamento em que a culpa se perpetua até ou especialmente em todo esforço de provar a própria inocência, como de fato no próprio julgamento que o delimitaria ou conteria. "Isso não transforma o juiz em réu?" (GS 2.2:427/SW 2:807 apud Comay, 2005, p. 38). Se isso sugere 
(para o desconforto de Scholem) uma indeterminação final quanto ao status da lei em sua forma mais pura ou mais paradigmática como um Juízo Final (agora indefinidamente prolongado e, portanto, finalizado devido a sua cumplicidade com seu objeto), talvez nenhuma distinção firme possa ser sustentada (pelo menos por meio de qualquer tribunal de julgamento ou discriminação "crítica") entre o ciclo mítico de retribuição e a justiça divina que "apenas expiaria". (GS 2.1:199/SW 1:249 apud Comay, 2005, p. 38).

Adorno ensaiou o problema com rigor irritante. A inevitável imbricação do mito e da iluminação implica a persistência da superstição no próprio "tabu" que a eliminaria e, como tal, a inevitável recaída de toda desmitologização em mais uma demonologia. A pureza "vazia" de um mundo do qual os ídolos foram eliminados não apenas "assume o caráter numinoso" de uma realidade ainda governada pelo medo e tremor (Adorno \& Horkheimer, 1984, p. 45/ 1972, p. 28 apud Comay, 2005, p. 38) mas também reprime o impulso mimético sem o qual a felicidade como tal - a própria possibilidade de reconciliação - permanece impensável. Assim, a inscrição inevitável da lei proíbe a representação dentro da lógica da autopreservação. (Êxodo 33:20: "“...] nenhum homem pode me ver e viver") A própria ausência pode, nesse sentido, tornar-se uma defesa ou fetiche. 'A destruição da ilusão não produz verdade, mas apenas mais um pedaço de ignorância, uma extensão do nosso "espaço vazio", um aumento do nosso deserto". (Nietzsche, Will to Power, §603 apud Comay, 2005, p. 38)

Todo movimento a partir daqui pode ser previsto. Toda Bilderverbot abstrata ou não-dialética tanto pressupõe como estimula fantasias pudicas de pureza que servem apenas para reforçar a mistificação sob contestação enquanto provê os confortos familiares da auto-mortificação. Os erros dos outros são, como de costume, para Adorno, instrutivos. De Kierkegaard a, sim, finalmente Schönberg, uma adesão servil à lei satisfaz uma necessidade imperiosa de punição enquanto libera um fluxo de produções fantasmagóricas. Assim, os infames diagnósticos de Adorno. O anseio de Kierkegaard por uma 'presença sem imagem' expressa o ascetismo (baseado em classes) que - em sua ânsia de repudiar toda aparência finita que obstrui o "bem infinito da felicidade" - apenas reinscrevia o último dentro de um cálculo sacrificial de "bens" ou aquisições, e, dessa forma, confundiria o "vazio do conceito" com a gratificação desejada (Adorno, 1962, p. 190/ 1989, p. 134 apud Comay, 2005, p. 39). O desejo de Veblen 
de uma ficha limpa é uma variação disso. A invectiva "esplendidamente misantrópica" contra o regime do kitsch ou do espetáculo (Prismas, 77/79 apud Comay, 2005, p. 39) pressupõe, como preço de seu insight, uma cegueira platonizante em relação ao mundo das "aparências enganosas"; isso apenas reproduz a fantasia puritana de um novo começo regulado pelo "ídolo" burguês de produção (Prismas, 83/83 apud Comay, 2005, p. 39). Ditto (mutatis mutandis), o rabugento sóbrio - ressentido, criptocristão - de um Huxley. "Sua ira contra a falsa felicidade sacrifica a ideia da verdadeira felicidade também" (Prismas, 105/103 apud Comay, 2005, p. 39). Nem mesmo Schönberg de Adorno sairá isento no final. O "emaranhamento de Schönberg na aporia da falsa transição" (Prismas, 170/164 apud Comay, 2005, p. 38) se trairá sintomaticamente, em Moisés e Arão, num monumentalismo neo-wagneriano que acabará por elidir a cesura entre o mito e o monoteísmo e assim minará o ímpeto iconoclasta da ópera: "Moisés e a dança ao redor do bezerro de ouro falam uma única língua" (Adorno, 1992, Quasi una fantasiap. 241 apud Comay, 2005, p. 39).

E assim por diante. Não é meu interesse aqui repreender Adorno por sua indelicadeza ou ensaiar a ladainha familiar de contra-acusações em relação às ofensas de Adorno no "grande hotel-abismo" da negação abstrata. Se há algo dolorosamente auto revelador no retrato de Adorno sobre o penitente furioso, esfregando-se em carne viva contra as barras da prisão da autonegação, a questão é menos de obter de Adorno uma autocrítica correspondente (tais confissões não são difíceis de extrair, e tendem de qualquer modo a neutralizar-se) do que considerar a demanda específica aqui colocada no pensamento. $\mathrm{O}$ próprio Adorno formula o dilema com precisão:

[...] como poderia ser pensada esta possibilidade, para que ela não seja abstrata e arbitrária como utopia condenada pelos filósofos dialéticos? Por outro lado, como o próximo passo pode adquirir uma direção e um objetivo sem que o sujeito saiba mais do que simplesmente lhe é dado de antemão? Caso alguém quisesse formular de modo diferente a questão kantiana, ela poderia hoje ser a seguinte: como é possível algo novo? (Prismas, 95/93/ Adorno (trad. Wernet \& Almeida), 1998, p. 89 apud Comay, 2005, p. 39-40). 
É exatamente nesse ponto que as relações entre Adorno e Benjamin acabarão se tornando um pouco tensas.

Adorno finalmente vai forçar a pergunta para Benjamin. Será que a versão do messianismo de Benjamin evita o dilema aqui apresentado como sendo bastante irresistível? Será que a imagem dialética acabará escapando da antítese entre a negatividade abstrata e a idolatria do dado? A questão também será, no final, a de Horkheimer. A "teologia ateológica" de Benjamin supera a antinomia entre o positivismo e o outro mundo? Todas as imagens do passado são condenadas a confirmar o presente precisamente insistindo na possibilidade de redenção?

Tanto Adorno quanto Horkheimer finalmente acusarão Benjamin de utopismo. Horkheimer acusa Benjamin de "idealismo": formar uma imagem dialética do passado é ocluir seu "fechamento" - "os mortos são realmente mortos" - e, assim, contrabandear algum tipo de horizonte escatológico de consolação (GS 2.3: $1332 \mathrm{f}$ apud Comay, 2005, p. 40). Adorno, como veremos, carrega o positivismo: formar qualquer imagem do futuro é inevitavelmente reificar o presente e assim enfeitar o status quo com sua apologia final. Cada um, portanto, virá diagnosticar o problema de Benjamin como o de "dialética insuficiente". De um lado, muita teologia, de outro não o bastante: as acusações simétricas tipificam o que, de fato, em breve se tornará o coro padrão de reprovações. "Janus encarado", "dois monitores" (Fuld, 1979 apud Comay, 2005, p. 40), o projeto de Benjamin cairá "entre duas cadeiras" (Scholem, Walter Benjamin: The Story of a Friendship, 1981 apud Comay, 2005, p. 40) - um enxerto tão desajeitado quanto a costura de um "capuz de monge" no corpo ressequido do materialismo histórico (Cf. Habermas, 1988, p. 114 apud Comay, 2005, p. 40).

\section{Ilusão de um futuro}

Um profeta voltado para trás. Friedrich Schlegel

Um texto inicial de Benjamin apresenta o problema "figurativamente" [in einem Bilde] (GS 2.1: 203 / R, p. 312 apud Comay, 2005, p. 40]. Se a disjunção entre teologia e materialismo implica simultaneamente uma reciprocidade, isso significa, de uma só vez, tanto um encerramento de 
qualquer escatologia secular progressista quanto uma reivindicação de suas afirmações mais profundas. "Nada histórico pode relacionar-se isoladamente a qualquer coisa messiânica". Tal noção não se refere apenas à vertente mística apocalíptica do judaísmo (como Scholem a interpreta), mas igualmente (algo muitas vezes esquecido pelos leitores de Benjamin) a uma certa tradição racionalista que vai do Talmude Babilônico até Maimônides e além. Isso significa que uma ruptura cataclísmica divide a ordem profana da história [olam hazeh] do reino de Deus [olam haba].

"Do ponto de vista da história", o Reino de Deus - redenção "não é o objetivo [Ziel], mas o fim [Ende]" (GS 2.1:203 / R, p. 312 apud Comay, 2005, p. 41). Toda determinação teleológica da história reduz-se a uma série reformistas de melhorias e ajustes estritamente instrumental - a oposição entre um Lenin e um Bernstein, nesse sentido, colapsa imediatamente - sancionando apenas a hegemonia dos dias atuais.

Assim, o catálogo familiar de renúncias - o historiador como o profeta voltado para trás (Schlegel), o moderno Orfeu que agora está prestes a voltar a perder sua Eurídice ao olhar para frente (Jean Paul). "Amaldiçoado é o cavaleiro que está acorrentado a seu cavalo porque ele estabeleceu para si mesmo uma meta para o futuro" (GS 2.2:436 / SW 2:814-815 apud Comay, 2005, p. 41). O anjo da história não capta um vislumbre sequer do futuro para o qual está de costas (GS 1.2: 697f / SW 4:392 apud Comay, 2005, p. 41). O "caráter destrutivo" que "desaparece" sem uma "visão" construtiva do futuro deixa "por um momento, pelo menos, o espaço vazio [leere Raum] no qual 'caminhos' ou 'encruzilhadas' podem se abrir" (GS 4.1:397f/SW 2:541-2 apud Comay, 2005, p. 41). Nenhuma imagem, similarmente, inspira o revolucionário: nem "o ideal dos netos libertados" nem a utopia "pintada nas cabeças" dos socialdemocratas (GS 1.2: 700 / SW 4: 394 apud Comay, 2005, p. 41). A visão de longo prazo do prognóstico historicista deve, portanto, contrair-se ao relâmpago da intervenção materialista histórica.

Benjamin explicitamente liga tal renúncia ao imperativo iconoclasta do judaísmo: "sabemos que os judeus foram proibidos de investigar o futuro" (GS 1.2:704/SW 4:397 apud Comay, 2005, p. 41). O momento messiânico - "poder messiânico" no sentido "fraco" (GS 1.2:694/SW 4:390 apud Comay, 2005, p. 41) - permanece tão inescrutável quanto os raios ultravioletas. "Quem quiser saber como uma 'humanidade redimida' seria constituída, sob que condições ela seria constituída e quando se pode contar com ela, coloca questões para as quais não há 
resposta. Ele poderia também perguntar sobre a cor dos raios ultravioleta" (GS 1.3:1232 apud Comay, 2005, p. 41).

\section{Kant avec Marx}

A imagem ( $\operatorname{sim}$ ) apresentada na primeira tese de Benjamin sobre a história indica a complexidade da questão. Qualquer que seja a natureza do entrelaçamento entre o anão "teológico" e o fantoche "materialista histórico" - conluio, co-dependência, contradição insubstituível - a própria figura invoca o próprio espectro da idolatria, ainda que apenas para desmistificá-la. O autômato é, em qualquer caso, consideravelmente menos automático que as imagens animadas de Dédalo. Celebrar o progresso desenfreado do "aparelho" - a socialdemocracia, de um lado, o stalinismo, do outro - é, por si só, cair vítima da ilusão transcendental que hipostatizaria o absoluto como já existia.

Kant e Marx unem forças desajeitadamente. O erro do socialismo utópico seria precisamente obscurecer a fronteira crítica entre o "reino da necessidade" e o "reino da liberdade" - os vocabulários de Kant e Marx curiosamente coincidem aqui - contaminando assim o próprio ideal do comunismo com as categorias empíricas dos dias atuais. Todo esforço para escrever "receitas para as oficinas do futuro" (Marx 'Afterword' to the second German edition of Capital, 1959, p. 1:26 apud Comay, 2005, p. 42) é culpado disso. Hegel viu isso claramente no prefácio à Filosofia do Direito quando rejeitou a demanda popular de "dar instrução" [Belehren] (Hegel, 1970, p. 27 apud Comay, 2005, p. 42) - construir o mundo "como deveria ser" - como pressupõe um colapso não-dialético da lacuna crítica entre Sein e Sollen, constativo e performativo, introduzindo assim o espectro da abstração não-mediada.

Para Marx, tal colapso marcou a cumplicidade secreta entre a ideologia e a utopia. O "jogo quimérico" da pintura "imagens extravagantes da futura estrutura da sociedade" (Letter of 19 October 1877 to Sorge, in Marx and Engels Selected Correspondance 184695, 1942 apud Comay, 2005, p. 42) só poderia branquear o existente precisamente "ao desconsiderar as sombras" (Korsch, 1967, p. 53 apud Comay, 2005, p. 42). Para Kant, tal colapso introduziria a ilegítima miscigenação de uma noumenologia teórica. Para a "lanterna mágica dos fantasmas", projetados pela teologia natural (Kant, 1956, p. 146 apud Comay, 2005, p. 42), corresponderia a ordenação do olhar que 
"contemplaria" ou "provaria" (Ibdem, p. 152 apud Comay, 2005, p. 42) o que deve permanecer adequadamente conjectural. O insight presumido [Einsichtsfähigkeit] usurparia, então, o lugar do "vislumbre fraco" [schwache Blick] da razão (Ibdem, p. 153). A redução da lei (liberdade) às condições da fenomenalidade só poderia reduzir a ação para as gesticulações "sem vida' de um "boneco" governado pelo medo e tremor. Iluminação hipertrófica viria deste modo significar nada além da tutela de uma natureza mortificada.

Em ambos os casos, o resultado é o fetichismo: descrever a redenção como uma extensão logica do presente é efetivamente confundir potencialidade com facticidade, liberdade com a necessidade e, portanto, apenas para confirmar a própria imersão no imaginário. Todo "ideal de netos libertos" (GS 1.2:700/SW 4:394 apud Comay, 2005, p. 42) não pode falhar, nesse sentido, em sua função ideológica. A fé em um futuro melhor santifica secretamente o dado ao oferecer imagens apaziguadoras que só distrairiam o espectador dos mais urgentes imperativos do dia. Honrar o falso deus do progresso é precisamente ser vítima do "sistema de espelhos" criando a ilusão de ótica de "transparência", esclarecimento ou visão clara. Se a teologia de hoje "tem que ficar fora de vista" (anão, "pequeno e feio") (GS 1.2:693/SW 4:389 apud Comay, 2005, p. 42), isto é, em última análise, porque a sua promessa contém a possibilidade ainda não-redimida de uma felicidade irrepresentável dentro a perspectiva dos dias atuais.

Tudo que Benjamin escreve, das primeiras exortações do movimento de juventude até as 'Teses sobre a Filosofia da História' finais - assim toda a difícil trajetória do hiper-idealismo ao messianismo - vai reiterar este ponto básico.

Os compromissos kantianos dos primeiros escritos estabelecem a problemática essencial. Se a tarefa da 'juventude' é manter aberto o 'abismo' crítico [Kluft] (GS 2.1:31 apud Comay, 2005, p. 42) entre o absoluto e o aparente, qualquer vislumbre prematuro da Ideia é equivalente ao "pecado mortal" (GS 2.1:32 apud Comay, 2005, p. 42) de naturalizar Geist por hipostatizar sua encarnação como já ou mesmo previsivelmente realizado.

Esta seria a arrogância teológica do "grande vidente" [der grofie Schauender] (GS 2.1: 32 apud Comay, 2005, p. 43). Benjamin vai mirar sob uma censura idêntica as conciliações contraditórias que foram de outro lado propostas pelo classicismo alemão, pelo Wandervogel, e pelo 
instrumentalismo assombrando Weimar, do acadêmico Berufsgeist ao otimismo progressista do Der Anfang - cada um dos quais será condenado por uma verdadeira "idolatria de Geist" (GS 3: 320 apud Comay, 2005, p. 43) em sua afirmação estéril do existente.

Nietzsche já havia identificado o estado militar moderno como o mais novo ídolo: um "cavalo da morte" mascarado em nome da própria vida, e assim "barulhento na elegância das honras divinas" (Nietzsche, 1968, p. 162 apud Comay, 2005, p. 43). Assim, para o jovem Benjamin (já traumatizado desde o início), a degradação da ideia no "espírito de 1914" e o aproveitamento do movimento de juventude para a patriótica ratificação do status quo.

Um certo conceito ótico pareceria, de fato, do começo ao fim, marcar a ideologia da "vida" como a que prolonga pela dissimulação da condição mortificada de uma natureza caída. Cada olhar para a "distância azul" (GS 2.2: 620 apud Comay, 2005, p. 43) - do Fernsicht romântico para o schauendes Bewutsein de um Jung ou Klages - acalmaria o espectador com o consolo de ideais inatingíveis ainda mais atraentes por serem eternas e assim presentes em sua própria ausência.

Não era precisamente tal distância ilusionista o "ideal urbanístico" (GS 5.1: 56 / AP, p. 11 apud Comay, 2005, p. 43) do Segundo Império? Os bulevares de Haussmann seduziriam o espectador com as longas perspectivas de visão prometendo uma gratificação infinitamente adiada (enquanto ao mesmo tempo efetivamente prevenindo a insurreição ao impedir a construção de barricadas). A Torre Eiffel ofereceria um ponto de vista seguro a partir do qual o espectador poderia admirar o seu progresso, reiterando o ponto geral subjacente à arquitetura de todas exposições mundiais do século XIX ("festivais modernos" (G16,5 apud Comay, 2005 , p. 39) permitindo que os trabalhadores olhem para o próprio maquinário que os tornava supérfluos), confirmando assim o conto de fadas de Saint-Simon de que o progresso é perspectiva de futuro muito próximo (U4a, 1 apud Comay, 2005, p. 43). A arquitetura de vidro das arcadas iria promover a ilusão do exterior no interior, prometendo uma exterioridade visual quando na verdade trata-se de reforçar a imanência do exterior (enquanto isso, as novas tecnologias de iluminação artificial transformariam a própria rua em um interieur doméstico), e assim apaziguaria a demanda por transcendência ao proporcionar a gratificação de uma bela visão. As multidões, que fazem sua peregrinação diária (A2,2 apud Comay, 2005, p. 43) a essas "grutas encantadas" ( $\mathrm{a}^{\circ}, 2$ apud Comay, 
2005, p. 43) do consumismo, desfrutariam do espetáculo de mercadorias cujo aparência de disponibilidade só ressalta o regime escopofílico da propriedade privada - "olhe, não toque" (G16,6 apud Comay, 2005, p. 43) - enquanto os panoramas do peepshow forneceriam a sensação visual de um movimento progressivo seguramente contido e orientado dentro dos limites privados de uma caixa.

Não é coincidência que a estrutura cruciforme das arcadas seja observada por Benjamin como cópia da arquitetura da igreja (A10a, 1 apud Comay, 2005, p. 43). Se a função das arcadas é de preservar o espaço de perspectiva com a mesma tenacidade das catedrais $\left(\mathrm{c}^{\circ}, 2\right.$ apud Comay, 2005 , p. 44), isto é, em última análise, porque aqui a fantasmagoria do progresso envolveria nada menos que uma fantasia generalizada de ressurreição. Coisas mortas prometem ganhar vida dentro desses "templos" encantados (A2,2 apud Comay, 2005, p. 44).

A visão procuraria confirmar-se através do retorno especular de um olhar que emana de um universo embalado como mercadoria, cujos olhares convidativos exemplificam os "caprichos teológicos" dos quais fala Marx. Assim, a rearticulação de Benjamin do capítulo clássico sobre o fetichismo da mercadoria: "coisas" adquirem fala, olhar, personalidade - as características antropomórficas a partir de agora removidas de uma humanidade completamente reificada - em uma transferência quiástica por meio da qual a transferência de "vida" como tal passa essencialmente por meio dos olhos. Daí a multiplicação de dispositivos ópticos projetados para suspender a hesitação do sujeito pelo sentido da visão. "As lojas dos oftalmologistas foram sitiadas" (Y4, lapud Comay, 2005, p. 44). O olhar fantasmagórico do objeto torna-se mais uma extensão protética projetada para confirmar os poderes eidéticos do sujeito (Lacan, 1978 apud Comay, 2005 , p. 44), cujas próprias ansiedades oculares traem-se em fantasias obsessivas de estranha não-reciprocidade e não-simultaneidade, como nas imagens de estátuas com olhos de joia de Baudelaire, prostitutas de olhos esbugalhados, olhos brilhando tão vagamente como espelhos $\left(\mathrm{c}^{\circ}\right.$, 2 apud Comay, 2005, p. 44) ou como vitrines - "tes yeux illumines ainsi que des boutiques" (GS 1.2: 649 / SW 4: 341 apud Comay, 2005, p. 44). "Jugendstil vê em toda mulher não Helena, mas Olímpia" (S9a, 2 apud Comay, 2005, p. 44).

A visão falsamente prometeria aqui realizar a fantasia do ego de uma imanência que elidiria a lacuna temporal ou a não-identidade em ação em toda experiência. Esse é o aspecto ideológico da "apoteose 
da existência" idealista (GS 1.1: 337/OT, p. 160 apud Comay, 2005, p. 44), exemplificada pelo classicismo de Weimar e teorizada como a reconciliação do finito e do infinito na plasticidade visual do símbolo - interpretada, como sempre, de uma perspectiva hegeliana - como a "incorporação sensual da ideia" (GS 1.1: 341/OT, p. 164 apud Comay, 2005 , p. 44). Se tal encarnação do numenal envolve uma animação espiritual da natureza e especificamente a sua auto-representação, delimitação e perfeição no ser humano - doravante seguramente instalado [eingestellf] ao longo do curso sacral de Heilsgeschichte (GS 1.1: 337/OT, p. 160 apud Comay, 2005, p. 44) - tal lógica de substituição [Stellvertretung] (GS 1.1: 341/OT, p. 165 apud Comay, 2005, p. 44) envolve uma distorção fundamental [Entstellung] (GS 1.1: 337/OT, p. 160 apud Comay, 2005, p. 44) subscrita por uma política de "domínio" e "usurpação" (GS 1.1: 336/OT p. 159 apud Comay, 2005, p. 44) em que não apenas a distância alegórica é ocluída, mas com ela a transitoriedade radical e o sofrimento de uma natureza finita (GS 1.1: 343/OT p. 166 apud Comay, 2005, p. 44).

Tal oclusão restringiria severamente o espaço potencial de cada ação. Em sua "transição sem emenda" do fenomenal para o numenal (a "imanência ilimitada do mundo ético no mundo da beleza"), a apoteose humanista do indivíduo aperfeiçoado restringiria o "raio de ação" a um mero "raio de cultura" [Bildungsradius] (GS 1.1: 337/OT p. 160 apud Comay, 2005, p. 44), interpretaria erroneamente a particularidade [das Einzelne] (GS 1.1: 343/077 p. 166 apud Comay, 2005, p. 44) como interioridade abstrata ou individualidade [Individuum] (GS 1.1: 337/OT p. 160 apud Comay, 2005, p. 44) - iria, em suma, condenar o sujeito ético as posturas "não-viris" da alma bela. As belas imagens ou "construções" [Gebilde] do simbólico apagariam o "abismo" (kantiano) [Abgrund] dividindo o "ser visual [bildliche Sein] do significado" (GS 1.1:342/OTp. 165 apud Comay, 2005, p. 45) - fenômeno do númeno - e assim apagaria a "linha irregular de demarcação" que grava os traços do semblante nãotransfigurado da natureza como "inoportuno, doloroso, malsucedido" (GS 1.1: 343/OT p. 166 apud Comay, 2005, p. 45): a linha da morte.

Em tal visão consoladora de uma natureza transfigurada, a "questão enigmática" [Ratselfrage] é suprimida em relação à existência humana em sua especificidade (histórica) como amarrada inexoravelmente a uma natureza caída e transitória (GS 1.1:343/OT, p. 166 apud Comay, 2005, p. 45). Tal oclusão acabará definindo a barbárie subscrevendo 
todo "documento de civilização" (GS 1.2: 696/ SW 4: 392 apud Comay, 2005 , p. 45) - o elo secreto entre humanismo e militarismo, "a unidade entre Weimar e Sedan". (GS 3:258 apud Comay, 2005, p. 45) A hidra de sete cabeças do Geisteswissenschaften ("criatividade, empatia, atemporalidade, recriação, Miterleben" etc.), com suas identificações vitais e seu "impulso lascivo pelo quadro geral" (GS 3: 286 apud Comay, 2005, p. 45) - o "bordel" do historicismo (GS 1.2: 702/SW 4:396 apud Comay, 2005, p. 45) - institucionalizaria a si mesmo nos "bosques sagrados" de "poetas atemporais" (GS 3:289 apud Comay, 2005, p. 45) e "valores eternos" (GS 3: 286 apud Comay, 2005, p. 45), num fanático "exorcismo da história" (GS 3: 289 apud Comay, 2005, p. 45) que entrincheiraria a hegemonia do "homem ocidental" sob o disfarce de uma universalidade depositada como se já estivesse ali. É nesse sentido que se diz que o classicismo culmina na "soteriologia germânica" (GS 3: 254 apud Comay, 2005, p. 45) cuja "Rettung" (GS 3: 257 apud Comay, 2005 , p. 45) (os espantos de Benjamin) dos mortos como Vorbilder (GS 3: 255 apud Comay, 2005, p. 45) - objetos de identificação empática resulta no sauve qui pent de um nacionalismo triunfante. Isto ocluiria a persistência de relações de poder herdadas através de um apelo as supostas continuidades de raça ou casta.

Não é coincidência aqui que tal soteriologia é considerada como sendo orquestrada por "videntes cujas visões aparecem sobre corpos mortos" (GS 3: 259 apud Comay, 2005, p. 45). Este é o olhar empático que encontraria retorno espiritual em um passado reanimado como precursor ou protótipo ancestral - assim também a eventual definição de aura de Benjamin como a capacidade do objeto inanimado de devolver o olhar - um avivamento idealizado dos mortos que inevitavelmente se acumula no lucro dos sobreviventes em sua marcha triunfal pelo continuum do tempo.

\section{Bilderflucht: ressuscitações críticas}

\section{$\operatorname{Re}($ sus)citações}

Isto não é para excluir a possibilidade de outro olhar, outra ressurreição. Em face da "visão florescente e resplandecente" [blumenhaft flammende Blick] do renascimento neoclássico, Benjamin se opõe ao 
(sim, ainda fértil) olhar de uma theoria que novamente invocaria os mortos - não, desta vez, por adulação, mas por interrogatório.

Devemos nos manter ... pela inconspícua [unansehnlichen] verdade, o laconismo da semente, da frutificação e, portanto, da teoria, que deixa para trás o feitiço da visão [Schau]. Se houver imagens atemporais, certamente não há teorias atemporais. Não a tradição, mas apenas originalidade [Ursprünglichkeit] pode decidir isso. A imagem original pode ser antiga, mas o pensamento genuíno é novo. É de hoje. Este hoje pode estar negligenciado, pressuposto. Mas, seja como for, é preciso agarrá-lo com firmeza pelos chifres, se se quiser colocar questões do passado. É o touro cujo sangue deve encher a cova, se os espíritos dos que partiram estão para aparecer [erscheinen] em sua borda. (GS 3:258 apud Comay, 2005, p. 46) ${ }^{2}$

Qual é exatamente a distinção introduzida aqui entre visão e "teoria"? Uma temporal, para começar. Quaisquer que sejam as aparentes continuidades entre flor e semente, entre "imagem" e "aparência", há uma oposição fundamental entre a violência mítica, que apagaria o tempo fechando a posição do presente (assegurando-o sub-repticiamente), e o sacrifício que vindicaria o presente precisamente expondo a sua vulnerabilidade e responsabilidade com - seu "secret rendez-vous" com (GS 1.2: 694/ SW 4: 390 apud Comay, 2005, p. 46) - o passado. (Wohlfarth in Smith, 225f).

Nesta distinção repousa a diferença entre "tradição" e "originalidade". A primeira, podemos interpretar, visa à re-ssur-reição: a transfiguração espiritual, a exaltação e a elevação dos mortos como "tesouros culturais" (GS 1.2:696/ SW 4: 91 apud Comay, 2005, p. 46) dentro do homogêneo continuum do tempo mítico. Este último visa re-sus-citação: a solicitação ou convocação dos mortos como $A b h u b$ ou remanescente inegável dentro do fraturado descontinuum de uma história trazida para uma cesura ou parada messiânica. A medida da "originalidade" não é, portanto, a abstração de um novo começo, definida dentro da "corrente de transformação" historicista (GS 1.1: 2261 OT, p. 45 apud Comay, 2005, p. 46). Em vez disso, ela expressará a si mesma de acordo com o "ritmo" difásico de uma repetição finita, em que o passado

\footnotetext{
${ }^{2}$ Resenha não traduzida para o português.
} 
é restaurado ou citado como radicalmente "imperfeito" e "incompleto" (cf. GS1.1: 226/OT; p. 45 apud Comay, 2005, p. 46).

A "visão" vê, assim, um rosto: o especular retorno a si mesmo do sujeito que se visualiza, à medida que se constrói narcisisticamente através do consolador tête-à-tête com o outro embelezado ou transfigurado. A "Teoria" vê uma máscara: a mancha da cabeça da morte cujo olhar vago marca a alteridade radical ou a não coincidência do observador e do observado, do olho e do olhar (a estrutura lacaniana parece aqui indispensável), (Lacan, Four Fundamental Concepts, p. 103) e, como tal, a aniquilação ou ferimento traumático do sujeito autoconsciente, refém da reivindicação de um passado imemorial. Tal não-coincidência marca a cena da história como facies hippocratica, alteridade não recuperável, a rua de mão única da transitoriedade e do sofrimento irredimíveis. (Lacan, Four Fundamental Concepts, p. 88). "É como algo incompleto e imperfeito que os objetos encaram fora da estrutura alegórica" (GS 1.1: 3621 OT, p. 186 apud Comay, 2005, p. 46).

A ressurreição simbólica - "visão" - chama assim os mortos como objeto de consumo: o objeto lamentado devorado ou introjetado como hospedeiro ou motivo de reflexão. Ressuscitação alegórica - "teoria" joga os mortos como remanescentes indigestos e lembrança inoportuna, a persistente demanda de matéria não-sublimada. Assim, a aparência do retorno dos espíritos como vampiros alimenta a vala do presente.

A ressurreição, como lemos no ensaio sobre Leskov, deve ser, nesse sentido, concebida menos como uma transfiguração idealizadora do que como um desencantamento radical (Entzauberung): libertação da humanidade do "pesadelo" da imanência mítica (GS 2.2-A58 / SW 3: 157-8 apud Comay, 2005, p. 47). Tal desmistificação não pode assumir uma oposição (mítica) entre o mito e o esclarecimento. A distinção operativa parece funcionar, ao contrário, dentro dos interstícios do mito em si, no ponto em que o mito aponta para o seu próprio exterior ou para as entranhas ocultadas. Estes são os pequenos "truques" dobrados dentro do tecido aparentemente sem costura da identidade mítica - a "magia libertadora" do conto de fadas com um tranquilizador final feliz - "a prova de Kafka de que medidas inadequadas, até mesmo infantis, podem servir para resgatar alguém” (GS 2.2: 415 / SW 2: 799 apud Comay, 2005, p. 47). 


\section{Teatros da Redenção}

A única ruptura do feitiço do imaginário é, portanto, através de um caminho profundo de imersão. Se (como Adorno insistiu), todo encerramento abstrato de imagens provoca um retorno alucinatório (como sintoma ou delírio), talvez seja, inversamente, o caso (isto é o que devemos considerar agora) que uma certa intensificação de imagens possa abrir uma brecha ou ruptura dentro do continuum ininterrupto da imanência mítica, e assim, de fato, apontar precisamente para a iminência do que é radicalmente imprevisível. A saber: a aparente violação do Bilderverbot pode de fato atestar seu poder mais produtivo.

A iconofilia em si (ou sua aparência) pode realmente vir a assumir proporções iconoclásticas. Escrevendo sobre a extravagância barroca a folie $d u$ voir (Buci-Glucksmann, 1986) de uma cultura que suplanta "mesmo os egípcios" (GS 1.1: 350/OT, p. 174 apud Comay, 2005, p. 47) em termos de especularidade - Benjamin percebe na "erupção de imagens" do mundo dos palcos um estilo nada menos que "sublime" (GS 1.1: 349 / OT, p. 173 apud Comay, 2005, p. 47). O distanciamento alegórico entre a aparência e a significação - o "abismo que separa o ser visual do significado" (GS 1.1: 342/OT p. 165 apud Comay, 2005, p. 47) - intensifica as possibilidades oculares de modo a aumentar a tensão escatológica entre imanência e transcendência, "assegurando assim para a última os mais altos rigor, exclusividade e implacabilidade concebíveis" (GS 1.1: 359/OT p. 183 apud Comay, 2005, p. 47). É de fato a própria profusão de imagens que bloqueará aqui qualquer fantasia de reconciliação prematura.

Se é parte da própria lógica da modernidade converter toda proibição de imagens em mais uma imagem de proibição - visto o deslumbramento de sinais negativos que atravancam a paisagem urbana da Rua de Mão Única ("Proibido colar cartazes!", "Atenção: degraus!", "Mendingos e ambulantes proibidos!", "Estas plantas são recomendadas à proteção do público") - serão necessárias medidas "heroicas" (cf. GS 1.2: 577/ $S W$ 4:44 apud Comay, 2005, p. 47) para negociar a aporia de tal especularidade sem fim.

A Rua de Mão Única apresenta vividamente a aporia agora familiar. Aqui, o "panorama imperial" do progresso é visto apenas para prolongar a claustrofobia do interior. Assim, a visão de um "glorioso futuro cultural" como um último fantasma doméstico: uma "miragem" consoladora projetada contra as "dobras de cortinas escuras" que 
mascaram e reforçam o confinamento dos dias atuais (GS 4.1: 98 / SW 1: 453 apud Comay, 2005, p. 48). Nem os marcos mais sublimes permaneceriam intactos. Os cumes estão encobertos. "Uma cortina pesada desliga o céu da Alemanha" (GS 4.1:99 / SW 1: 453 apud Comay, 2005, p. 48). Obviamente, não haveria escapatória aqui para apelar à suposta neutralidade de um "ponto de vista crítico", "aspecto geral" ou "perspectiva" (GS 4.1: 132/ SW 1:476 apud Comay, 2005, p. 48). Tal perspectiva só poderia contrabandear na ilusão óptica do panorama, intensificaria a fantasmagoria no próprio esforço de ver através dele, e portanto reforçaria a imanência precisamente no clamor à externalidade ou transcendência. Este é o pesadelo do teatro total - o aquário de Proust (Proust, 1983, 2:35ff), se não o de Aragão (1971, p. 28) - a não-saída ou "beco sem saída" (como foi batizada originalmente em Rua de Mão Única) de nossa espetacular modernidade:

E como se se estivesse aprisionado em um teatro e se fosse obrigado a seguir a peça que está no palco, queira-se ou não, obrigado a fazer dela sempre de novo, queira-se ou não, objeto do pensamento e da fala. (GS 4.1:98/SW1:453 Benjamin, (trad. Torres Filho) 1997, p. 23 apud Comay, 2005, p. 48)

A "saída" aqui pode ser figurada, na verdade, adequadamente encenada, apenas como uma pausa dramática dentro da fantasmagoria da visão total. Se toda tentativa prematura de abandonar secretamente $o$ círculo prolonga-se o que ela abandonaria (cf. GS 4.1:85f./SW 1: 445 apud Comay, 2005, p. 48), qualquer ruptura exigirá uma certa colaboração com forças míticas e, portanto, assumirá um aspecto infinitamente ambíguo. 'Costume Wardrobe 'apresenta a cena da redenção como nada mais e nada menos do que uma ocorrência teatral:

Repetidas vezes, em Shakespeare, em Calderón, as batalhas preenchem o ato, e reis, príncipes, atendentes e seguidores 'entram, fugindo'. O momento [Augenblick] em que se tornam visíveis aos espectadores os leva a um impasse. O voo da dramatis personae está preso pelo palco. Sua entrada no campo visual [Blickraum] de pessoas não participantes e verdadeiramente imparciais permite que o assediado desenhe um respiro, banha-os em um novo ar. A aparição no palco daqueles que entram 'fugindo' tira dali seu sentido oculto. Nossa leitura desta fórmula está imbuída de expectativa de um lugar, uma luz, um clarão de luz de 
fundo [Rampenlicht], no qual nosso próprio voo pela vida pode ser igualmente protegido na presença de observadores desconhecidos. (GS4.1:143/SW1:484 apud Comay, 2005, p. 48)3.

A redenção - respiração, aqui, como sempre - é assim figurada dentro do Blickraum ou Bildraum da visibilidade consumada. O descentramento do olhar (a transformação do espectador em potencial espetáculo) é aqui apresentado como reviravolta sem simetria ou reciprocidade empática. Uma distância brechtiana caracteriza tanto a posição de visualização como a do objeto visualizado.

Esta é a "astúcia" (GS 5.2: 1213 / AP, p. 907 apud Comay, 2005, p. 49) - "teleológica" - por meio da qual o sonho, intensificando-se, avança em direção ao seu próprio despertar.

Haverá, então, "ainda uma esfera de imagens [Bildraum], e, mais concretamente" - e por isso mesmo - "de corpos [Leibraum]" (GS 2.1:309/SW 2: 217 apud Comay, 2005, p. 49). Se a época moderna, apesar ou devido à sua especularidade hipertrófica, representa o máximo aleijamento ou mutilação da imaginação ( $G S$ 1.2:611/SW4:316), só a imagem virá para redimir um corpo e um corpo político fraturado irremediavelmente pela força do tempo. A expulsão da "metáfora moral da política" (GS 2.1: 309/SW 2: 217 apud Comay, 2005, p. 49) - a eliminação do gradus ad parnassum social-democrata (GS 2.1: 308 / SW 2: 216 apud Comay, 2005, p. 49) - requer precisamente a "abertura" ou elaboração de uma esfera de imagem concorrente através da qual o corpo se reconfigura no tempo.

Este não é o projeto da Bildung estética. Nesta versão de um último julgamento materialista, o corpo sofredor se submete a uma "justiça dialética" (a reescrita de Benjamin do Hegelian Bacchanalian revel) segundo a qual "nenhum membro permanece ininterrupto [unzerissen]" (GS 2.1: 309/SW 2: 217 apud Comay, 2005, p. 49). A reconstituição de uma nova physis (GS 2.1: 310/SW 2: 217 apud Comay, 2005, p. 49) ou "novo corpo" (GS 4.1: 148/SW 1: 487 apud Comay, 2005, p. 49) para o coletivo corpóreo [leibliche Kollektivum] (GS 2.3: 1041 apud Comay, 2005, p. 49) envolve a quebra de toda fantasia de harmonia ou imanência estética. Se Benjamin aqui anuncia o início de uma verdadeira "revolta de escravos da tecnologia" (GS 3: 238 apud Comay, 2005, p. 49), isso

\footnotetext{
${ }^{3}$ Sem tradução para o português.
} 
não deve ser confundido com a consolação ascética que iria (como no futurismo) vitalisticamente negar ou estetizar as condições mortificantes de uma vida danificada. Portanto, esta não é a ressurreição de um corpo ou corpo político espiritualizado dentro da comunidade eterna da humanidade. Se é um corpo fissurado, epiléptico (GS 4.1: 148/SW 1: 487 apud Comay, 2005, p. 49) que deve entrar na corte final do julgamento, isto é precisamente para repelir toda solidariedade mítica sugerida pelo "ídolo" de uma "humanidade harmoniosamente e perfeitamente formada" - o "fantasma do homem não político ou natural" ( $G S$ 2.1, 364/SW 2:454 apud Comay, 2005, p. 49). "O assunto da história: não a humanidade [die Menschheit] mas o oprimido" (GS 1.3:1244 apud Comay, 2005, p. 49). "Trabalhar em locais importantes na esfera das imagens" é precisamente proteger o impulso revolucionário de degenerar em um "mau poema na primavera" (GS 2.1: 309/SW 2: 217 apud Comay, 2005, p. 49): essa é a "organização do pessimismo" sobre qual Benjamin escreve.

Poder-se-ia argumentar que as conhecidas séries de operações de salvamento de Benjamin (romantismo, surrealismo, Proust, Baudelaire, Brecht, Kafka, cinema, fotografia, e assim por diante) serão dirigidas precisamente para esse núcleo do imaginário que desafia a idealização e que, portanto, negocia uma abertura para o imprevisto. $\mathrm{O}$ Bilderverbot bíblico é assim refinado como um Bilderflucht (J54,2 apud Comay, 2005, p. 49): um voo da imagem mítica para a imagem dialética despojada de toda força consoladora. A "óptica dialética” de Benjamin colocará a imagem contra a imagem.

O que quer que esteja em ação para colocar a história cultural contra o deposito de (auto)-engano historicista - Goethe contra Gundolf, Romantismo contra Sturm und Drang, Kafka contra Brod, cinema contra Riefenstahl, Mickey Mouse contra a Disney, surrealismo contra o "espiritualismo" obsoleto que desmoronaria o impulso visionário no ocultismo dos mitólogos e médiuns (GS 2.1: 298/SW 2: 209 apud Comay, 2005, p. 50) - qualquer que seja a força e legitimidade das reescritas específicas de Benjamin, será em cada caso uma questão de recuperação ao invés de repressão das possibilidades oculares, e como tal a vindicação de um imaginário sobrecarregado pela "ambiguidade" essencial que anuncia a própria "lei" da dialética remodelada ( GS 5.1: 551 AP, p. 10 apud Comay, 2005, p. 50).

Se é dentro do teatro-mundo que a "esperança dos desesperados" de Kafka é para ser realizada ( $G S$ 52.2: 415/SW 2: 799 apud Comay, 2005, 
p. 50) - céu falso, asas de papel: Adorno virá de fato a suspeitar disso (GS 2.3: 1177f apud Comay, 2005, p. 50) - isso é precisamente porque a única "saída" (como no Relatório para uma Academia) é recapturar o último vestígio de um impulso mimético reprimido (GS 2.2: 423/SW 2:804 apud Comay, 2005, p. 50). "As faculdades miméticas e críticas não podem mais ser distinguidas" (GS 2.3: 1050 apud Comay, 2005, p. 50). Se a busca frenética de Proust por imagens envolver o "vício" ("somos tentados a dizer, teológica") da curiosidade obsequiosa, isso de fato implicará o inevitável enredamento de toda imagem de redenção dentro da "floresta encantada" [Bannwald] (GS 2.1:313/SW 2: 239 apud Comay, 2005, p. 50) da culpa mítica.

Tudo isso levará em breve as acusações previsíveis: feitiçaria, cooptação, identificação com o agressor.

\section{Bilderstreit: Adorno contra Benjamin}

\section{Mosaicos}

É com o abortivo Passagenwerk - "o teatro de todos os meus conflitos e todas as minhas ideias" (GB 3: 503 / C, p. 359 apud Comay, 2005 , p. 50) - que as questões surgem primeiro na mente. Benjamin será observado jogando como aprendiz de feiticeiro, hipnotizado por aquilo que ele iria subverter. Especificamente: se é o regime ocular da modernidade que apresenta a face da história como absoluta monstruosidade - não apenas uma "cabeça superdimensionada" (G ${ }^{\circ} 17$ apud Comay, 2005, p. 50), mas também (como Marx também observou Marx \&Engels, 1962, 23:15) uma "cabeça da Medusa". (GS 1.2: 682 apud Comay, 2005, p. 50) - Benjamin ficará petrificado com o que vê.

Em 1935, Adorno irá de fato acusá-lo de capitular à força do capital. Representações panoramáticas do panorama, representações caleidoscópicas do caleidoscópio - a técnica de montagem é encontrada aqui não apenas para simular a do surrealismo, mas efetivamente para adotar o que será, para Adorno, a sua posição irremediavelmente conciliatória. Uma afirmação enigmática, Behauptung, seria detectada na determinação fisionômica de Paris como Hauptstadt der neunzehnten Jahrhunderts, guia ou capital do século XIX (um título "privado" traduzido para o francês por Benjamin $(G B$ 5:83-4/C, p. 482 apud Comay, 2005 , p. 51) e eventualmente descartado), que seria assim transfigurado 
como nada menos que a figura proscrita da utopia. Paris, lugar decapitado de oportunidades revolucionárias perdidas (Cf. Ivornel, 1986, p. 61-84), seria reintegrado ao palco central, de modo a fornecer a cena sedutora ou espetáculo de redenção. Caput mortuum seria assim figurado ou transfigurado como - precisamente, rosto.

Não é simplesmente que Benjamin irá agressivamente depender das imagens para contar uma história (cf. N1l, 4); nem que o que começa como um "álbum" (GS 5.2: 1324 apud Comay, 2005, p. 50) em breve colapsará sob seu próprio peso em um "campo de entulho" (GB 4: 1121/C, p. 396 apud Comay, 2005, p. 50) de proporções tipo Bouvard-andPecuchet; nem mesmo que as imagens específicas a serem selecionadas aqui - a conhecida lista de compras: passagens, trapeiros, varandas e o resto - irão carregar, para Adorno, um selo irremediavelmente consumista.

Nem é apenas (embora isso não seja irrelevante) uma questão dos respectivos compromissos de Adorno e Benjamin como críticos culturais - alta cultura versus cultura de massa, música versus fotografia, aural versus visual e todo o restante. Se a queixa de Adorno eventualmente virá a se cristalizar no notório assalto sobre a cultura cinematográfica como hipnose de massa, talvez seja menos o exemplo específico do meio que é significativo aqui do que a lógica real subjacente ao ataque. Se Benjamin veio a ser repreendido, seguindo o ensaio da obra de arte, pelo "anarquismo romântico" (GS 1.3: 1003 apud Comay, 2005, p. 50) que hipostatizaria a "consciência realmente existente dos trabalhadores realmente existentes" (GS 1.3: 1005 apud Comay, 2005, p. 51) e, assim, antecipar a revolução precisamente prefigurando-a - a acusação essencialmente reproduz a crítica de Lênin a Luxemburgo - é importante considerar as premissas específicas aqui em jogo. Sustentar o que será de outro modo uma lamentação [jeremiad] convencional que liga a cultura midiática à idolatria em massa (do Salon (Baudelaire, 1979, 2:614-19) de Baudelaire, de 1859, a Jacques Ellul) é um confronto ante a natureza da memória e a temporalidade específica da imaginação histórica.

A própria concepção de imagem dialética está aqui em jogo. $\mathrm{O}$ olhar 'estereoscópico' de Benjamin (cf. N1, 8 apud Comay, 2005, p. 51) para a constelação intempestiva de um passado não realizado e um presente regressivo será condenado como duplamente afirmativo, na medida em que entrincheiraria simetricamente ambos, segundo Adorno, dentro de um horizonte compartilhado de conciliação. Em suma: qualquer imagem de uma "humanidade redimida" vislumbrada de dentro do sonho 
fantasmagórico da modernidade só poderia transgredir a Bilderverbot e, assim, inevitavelmente, reciclar a ideologia como Utopia.

A citação de Michelet feita por Benjamin ("Avenir! Avenir!") é aqui decisiva: "Chaque époque rêve la suivante" (GS 5.1:46 / AP, p. 4 apud Comay, 2005, p. 51). Benjamin lê aqui a ambiguidade crucial de toda imagem - a "lei da dialética paralisada" (GS 5.1: 55 / AP, p. 10 apud Comay, 2005, p. 51) - o entrelaçamento entre regressão e utopia visivelmente em ação em todos os tempos. "No sonho em que toda época vê em imagens a época que a sucederá, a última aparece acoplada a elementos de pré-história - isto é, de uma sociedade sem classes" ( $G S$ 5.1:46/AP, p. 4 apud Comay, 2005, p. 51). Adorno lê em tal acoplamento a monstruosa cumplicidade da nostalgia e do etéreo. Klages casado com Fourier: uma relação "linear" com o futuro, tecida do casulo da consciência coletiva, uma realização alucinatória do desejo, destinada apenas a acomodar o presente, colocando-se não-dialeticamente como verdade $(C$, p. 495 apud Comay, 2005, p. 52). Em síntese: ao sucumbir ao "feitiço da psicologia burguesa" ( $B r$ 2:674/C, p. 497 apud Comay, 2005, p. 52) Benjamin não apenas desviará a psicanálise pelas linhas junguianas, como também desconsiderará a enfática negação de Freud de todo significado profético do trabalho do sonho. (Freud, 1953, 5:621). "Toda época não apenas sonha a próxima", mas ao fazê-lo a pressiona "dialeticamente" (GS 5.1: 59 / AP, p. 13 apud Comay, 2005, p. 52) e com "astúcia" (GS 5.2: 1213/AP, p. 907 apud Comay, 2005, p. 52) em direção ao seu próprio despertar. Esta é a rearticulação proustiana de Benjamin da List der Vernunft de Hegel: o "cavalo de Tróia" (K2,4 apud Comay, 2005, p. 52) instalado no sono onírico da cultura de massa do século XIX. Adorno, talvez o melhor freudiano aqui, veria no propósito essencial do sonho como o prolongamento de nosso sono dogmático, e assim lê Benjamin como um apologista da continuidade ou "imanência" consumada (Br 2: 672f./C, p. 495f apud Comay, 2005, p. 52). A imagem dialética, nesse sentido, perderia assim o seu "poder libertador objetivo" e se resignaria, então, à reprodução estéril de das Nächste.

Adorno não será nem o primeiro nem o último a acusar Benjamin de idolatria. Em 1938, o efeito-montagem representará a desintegração derradeira do imperativo Mosaico nas concatenações do puro mosaico - uma "enumeração supersticiosa de materiais" $(B r 2: 787$ / C, p. 583 apud Comay, 2005, p. 52) que em sua abstenção "ascética" da elaboração conceitual se restringiria "demoniacamente" $(B r 2: 783$ / C, p. 580 apud 
Comay, 2005, p. 52) a uma 'encantação' piedosa (Beschworung) da realidade nua e crua ( $\operatorname{Br} 2: 786$ / C, p. 582 apud Comay, 2005, p. 52).

O status de "teoria" como tal está em jogo. Desde o princípio, terá sido para Benjamin uma questão de refutar o "suave empirismo" de um Goethe (GB 3: 332 e $G S$ 1.1: 60/SW 1: 148 apud Comay, 2005, p. 52). ("Tudo que é factual já é teoria" ( $C$, p. 313 apud Comay, 2005, p. 52 apud Comay, 2005, p. 52)). Isso se aplicará, mutatis mutandis, à salvação neoplatônica dos fenômenos propostos no prefácio do Trauerspielbuch ("O valor dos fragmentos do pensamento é tanto mais decisivo, quanto menos imediata é sua relação com a ideia subjacente" (GS 1.1: 208/ OT, p. 29 apud Comay, 2005, p. 52)); à arte sem arte do contador de histórias desaparecido ('faz parte da arte de contar histórias, manter uma história livre de explicações' (GS 2.1: 445/SW 3: 148)); è̀ 'técnica' apresentada pelo Passagenwerk ("Método deste trabalho: montagem literária. Eu não preciso dizer nada. Apenas mostrar" (Nla, 8 apud Comay, 2005, p. 52)). Seja qual for a mudança - o próprio Benjamin a descreve como nada menos que "revolução total" [vollkommenen Umwälzung] (GB 5: 88 / $C$, p. 486 apud Comay, 2005, p. 52) - entre a problemática "metafísica" (palavra de Benjamin) anterior e o plano cultural materialista no trabalho tardio, o compromisso micrológico com o objeto persistentemente renegaria toda reivindicação de uma teoria panóptica e, portanto, qualquer totalização estável ou consistente do que aparece. Se a "salvação dos fenômenos" coincide aqui (como sempre) com a "apresentação de ideias" (GS 1.1: 215/OT p. 35 apud Comay, 2005, p. 52), isso é precisamente porque os fenômenos devem ser despojados de qualquer inviolabilidade ou unidade "integral" ou auto subsistente, e submetido à fraturação, dispersiva e reintegradora, mas também constantemente auto-revisada, do pensamento composto (GS 1.1:213/OT p. 33 apud Comay, 2005, p. 53). Isso marca a continuidade fundamental, seja lá o que Adorno suspeitasse, entre o mosaico filosófico do Trauerspielbuch e o muito difamado (por Adorno) "método surrealista".

Nada menos do que a própria vida está aqui posta em xeque. A questão, em última instância, diz respeito à própria possibilidade de ressuscitação. Uma "fidelidade sem esperança as coisas" (GS 1.1: 333 / OT, p. 156 apud Comay, 2005, p. 53) exigirá nada menos do que uma descida às 'cinzas': uma virada para o remanescente mais recalcitrante ou "pesado" de matéria não-sublimada (GS 1.1: 334/OT, p.157 apud Comay, 2005, p. 53). Se a versão de Benjamin da "teoria no sentido mais 
estrito" ( $C$, p. 58 apud Comay, 2005, p. 53) coloca em risco a aparência de um certo empirismo, é justamente a partir de uma ambição teológica de “deixar o que é 'criatura' falar por si" (GB 2: 232 / C, p.313 apud Comay, 2005, p. 53): isto é, restaurar precisamente abstendo-se de ventriloquizar ou representar antropomorficamente a voz de uma natureza caída e, portanto, de fato, de uma história - agora mortificada - como instintiva. Esta é a alquimia crítica (GS 1.1: 126/SW 1: 298 apud Comay, 2005, p. 53) ou "pedra filosofal" prometida pelo método "construtivo" (GB 5: 142 / C, p. 507 apud Comay, 2005, p. 53) - esperança para os desesperados (cf. GS 1.1: 201 / SW 1: 356 apud Comay, 2005, p. 53) - o olhar alegórico voltado para aquilo que, em sua própria transitoriedade e ruína, figura precisamente como a cifra da ressurreição (cf. GS 1.1: 405f / OT p. 232 apud Comay, 2005, p. 53). "Na mônada", escreve Benjamin, "tudo o que foi miticamente paralisado [in mythischer Starre lag] como evidência textual ganha vida" (GB 6: 185 / C, p. 588 apud Comay, 2005, p. 53).

A reescrita de Goethe por Benjamin é crucial. Se Benjamin insiste em sua apresentação sobre um sentido de uma "elevada visualidade" [gesteigerte Anschaulichkeit]" (N2a,6 apud Comay, 2005, p. 52) que supere tanto a "deteriorada" [shabbiness] historiografia marxista quanto a "barateza" do tipo burguês (GS 5.2:1217/AP, p. 911 apud Comay, 2005, p. 52), o modelo final para tal método pictórico é ser derivado dos estudos morfológicos de Goethe (O73 apud Comay, 2005, p. 53). Tal como acontece com o Urpflanze, a revelação do geral nos detalhes envolve um certo "desdobramento" - "como uma folha", escreve Benjamin (N2a, 4 apud Comay, 2005, p. 52) - neste caso, da constelação temporal específica (nunca estável) dentro da qual todo "pequeno momento singular" (N2a, 6 apud Comay, 2005, p. 52) deve ser inscrito.

Mas o que é anunciado aqui como uma "transposição" ou "tradução" [Übertragung] do princípio morfológico da observação do "contexto pagão da natureza para os contextos judaicos" - plural - "da história" (N2a, 4 apud Comay, 2005, p. 53) pareceria obedecer uma lógica de tradução bastante familiar, de acordo com a qual o original (e de fato o conceito original do originário) não permanecerá de maneira alguma intacto. O que quer que esteja em funcionamento na "transferência" de atenção de Benjamin de uma natureza orgânica para uma história da natureza despojada de toda realização imanente, fica claro que os conceitos tanto da natureza quanto da história terão sido radicalmente transformados. 
A "síntese genial" de Goethe da essência e da aparência teria envolvido não apenas o "símbolo ideal" (GS 6:38 apud Comay, 2005, p. 53) - atemporal, total, instantâneo - mas também teria privilegiado o domínio da própria "vida" biológica como objeto específico de "percepção irredutível" (GS 6:38 apud Comay, 2005, p. 53). O princípio benjaminiano da montagem, em contraste, não apenas introduzirá a distância alegórica ou a não-simultaneidade para o "interior arborizado" (GS 1.1: 342/OT, p. 165 apud Comay, 2005, p. 54) da mônada, mas, além disso, e por essa mesma razão, forçará uma revisão fundamental do próprio conceito de "vida" em si.

Se a abrangência micrológica da particularidade lumpeniana envolve como sua suposição "verdadeiramente problemática" o desejo de "não abrir mão de nada" (N3,3 apud Comay, 2005, p. 54) - considerar nada irremediavelmente perdido ou subestimado - isto é precisamente devido a uma conviç̧ão, nada menos do que teológica, a respeito da "indestrutibilidade da vida mais elevada em todas as coisas" (N1a, 4 apud Comay, 2005, p. 54). Tal apelo à vida antecipará qualquer antítese fixa entre vivo e morto - positiva e negativa, para frente e para trás, ou, nesse sentido, destruição e construção ("e assim por diante in infinitum" (N1a, 3 apud Comay, 2005, p. 54) - assim como impedirá qualquer teodiceia organicista ou "naturalista vulgar" (N2,6 apud Comay, 2005, p. 54), seja ao longo de linhas progressivas-evolutivas ou regressivas de Spengler (N1a, 3 apud Comay, 2005, p. 54).

As figuras conhecidas do cinegrafista e cirurgião novamente convergem aqui (como no ensaio artístico (GS 1.2: 495f / SW 4: 263 apud Comay, 2005, p. 54)) para iniciar a cesura ou corte a ser infligido no corpus histórico como cadáver vivo. Qualquer que seja a natureza da "operação" materialista histórica - congelando a imagem, escolhendo o ângulo, ajustando a iluminação, clicando no obturador (GS 1.3: 1165 apud Comay, 2005, p. 54) - é somente dentro da "câmara escura do momento vivido" (GS 2.3: 1064 apud Comay, 2005, p. 54) (semelhantemente a câmara obscura da ideologia) que o "desenvolvimento" total da imagem deve ser alcançado. Em todo caso, isso dever ser distinguido do olhar [Schauen] burguês hipnotizado pelo espetáculo da história como uma exibição de "imagens coloridas" (GS 1.3: 1165 apud Comay, 2005, p. 54). "Uma mudança constante na perspectiva visual" [Verschiebung des Gesichtswinkels] eventualmente apresenta todos os negativos como positivos de acordo com uma teologia da "apokatastasis histórica" (N1a, 
3 apud Comay, 2005, p. 54) - a fonte herética é Orígenes (cf. GS 2.2: 458 I SW 3: 159 apud Comay, 2005, p. 54) - até no "meio dia da história" (N15,2 apud Comay, 2005, p. 54), e fora das "nuances dialéticas" (N1a, 4 apud Comay, 2005, p. 54) da óptica messiânica ("luz para sombra, sombra para luz" (GS 1.3: 1165 apud Comay, 2005, p. 54), e assim por diante), "a vida nasce de novo" (N1a, 4 apud Comay, 2005, p. 54). "Como flores que voltam suas corolas para o sol, assim o que foi aspira, por secreto heliotropismo, a voltar-se para o sol que está a se levantar no céu da história. Essa mudança, a mais imperceptível de todas, o materialista histórico tem que saber discernir" (GS 1.2: 695 / SW 4: 390 Benjamin, (trad. Gagnebin), 2005, p. 58 apud Comay, 2005, p. 54).

Adorno, não obstante, suspeitará aqui de um resíduo naturalista não-sublimado - se não, de fato, algo como o "neopaganismo" parodiado por Baudelaire. Se o método construtivo será atacado por colapsar a precária dialética do conceito e da intuição, racionalidade e mimesis, universal e particular, é porque, como todo empirismo, carrega a mancha de uma razão que mascararia sua própria dominação sobre o próprio objeto que reivindicaria a deixar falar. Subjacente à modéstia teórica que se abstém da intervenção conceitual seria a arrogância secreta de uma racionalidade destinada a dominar a própria natureza que ela redimiria. Este é Odisseu, amarrado ao mastro, fascinado por uma canção de sereia cujo último encanto nada mais será do que a auto sedução de seu próprio ego controlador (Cf. Dialetic of Enlightenment, p. 43-80). Assim, a "pedra filosofal" encobria a arrogância como humildade. De fato, será o próprio projeto de Benjamin que, em última análise, será acusado de auto santificação.

Gretel brincou certa vez que você vivia nas cavernosas profundezas de suas Passagens e, portanto, ficou horrorizado de concluir o trabalho porque temia ter que deixar o que construiu. Então, vamos encorajá-lo a nos permitir entrar no Santo dos Santos. Eu acredito que você não tem motivos para se preocupar com a estabilidade do santuário, ou qualquer motivo para temer que seja profanado. ( $B r 2: 788$ / C, p. 583 apud Comay, 2005, p. 55)

Quero amar e perecer que uma imagem não permaneça uma mera imagem Nietzsche, Assim falou Zaratustra 
Talvez seja desnecessário aqui recitar longamente o conhecido coro de defesas: o que é "dialético" na imagem é, para Benjamin, precisamente o que deve impedir qualquer assimilação no contínuo do tempo mítico. A historicidade específica da imagem excluiria igualmente nostalgia e presságio, e, como tal, minaria qualquer relação evidente ou pictórica com o que poderia vir. Como já efetivamente se passou, ou prestes a desaparecer (GS 1.2: 590 apud Comay, 2005, p. 55) - o modelo da inflação monetária nunca está distante (cf. GS2.2: 620 apud Comay, 2005 , p. 55) - a imagem perturba toda reconstrução contemplativa e assim também todo modelo consolador do que pode ser. Jung e Fourier seriam aqui simetricamente desviados.

Como a memória de um futuro perdido e a antecipação de uma ausência futura - "tristeza pelo que foi e desesperança em direção ao que está por vir" (GS 1.2: 586 apud Comay, 2005, p. 55) - a imagem expressa de fato a estrutura rigorosamente traumática de toda experiência. A lógica da latência introduziria uma anacronia fundamental à imagem, de modo que toda e qualquer antecipação da redenção - a "sociedade sem classes" - aparecesse, ao mesmo tempo, não apenas radicalmente precipitada, mas de fato devidamente legível apenas postumamente, se não, de fato, tarde demais. Se a tão falada Auseinandersetzung (GS 5.2: 1160 apud Comay, 2005, p. 55) com Jung, Klages e companhia nunca e propriamente conhecida como tal (na verdade, é tentador culpar o próprio Adorno tanto quanto a qualquer um por esse diferimento), fica claro que qualquer imagem de Urgeschichte poderia apontar apenas para uma "origem" fraturada por uma retroatividade que impediria toda recuperação e, portanto, igualmente, toda visão segura de um fim consumado ou futuro. Se na imagem dialética a iluminação mútua entre passado e presente é tipicamente caracterizada tanto como "lampejo" (N2a, 3 apud Comay, 2005, p. 55) quanto como "explosivo" (O०56 apud Comay, 2005, p. 55), isso ocorre porque o que está rompido aqui é tanto a imanência de cada época quanto a imanência da subjetividade, seja de um indivíduo ou de um fantasma coletivamente hipostatizado em trajes junguianos.

"O lugar onde se encontra [a imagem] é a linguagem" (N2a,3 apud Comay, 2005, p. 56). Se a "imagem autêntica" é a "imagem lida" - a familiar problemática barthesiana se abre aqui (Barthes, 1981) - é precisamente porque o "ponto" [Punktum] de legibilidade envolve o reconhecimento do tempo atual da interpretação no seu ponto de 
responsabilidade mais 'crítico, perigoso' em relação ao passado (N3,1 apud Comay, 2005, p. 56). Tal pontualidade destruiria [zerspringen] de fato qualquer plenitude atemporal da verdade e, assim, todo relacionamento contemplativo com o que aparece.

A estrutura temporal da imagem converte visão em leitura, imagem em texto. Se o que é essencial na imagem é que ela "não é vista antes de ser lembrada" (GS 1.3: 1064 apud Comay, 2005, p. 56), toda profecia se tornaria inevitavelmente a profecia culposa de um presente que não pode deixar de chegar tarde (cf. N13,1 apud Comay, 2005, p. 56). "O inferno não é nada que nos aguarda, mas esta vida aqui" (Strindberg) (N9a, 1 apud Comay, 2005, p. 56). Isso de fato definirá a forma essencial da iconoclastia de Benjamin. 'Adorar a imagem da justiça divina na linguagem ... essa é a genuína travessia judaica' pela qual o feitiço mítico deve ser quebrado (GS 2.1: 367 / SW2: 244 apud Comay, 2005, p. 56).

\section{Conjurações}

Nem precisamos agora ensaiar os inevitáveis reflexos e réplicas. Se a retórica de exorcismo um tanto histérica de Adorno segue uma lógica previsível de conjuração - demonologia / contra-demonologia (Derrida, 1994) - não demorará muito para expor a própria dependência secreta de Adorno da fantasmagoria que ele procuraria "liquidar" $(\operatorname{Br} 2: 7847 \mathrm{C}, \mathrm{p}$ 580 apud Comay, 2005, p. 56). Assim, o apelo frenético à "mediação" como a varinha mágica é para "quebrar o feitiço" $(B r 2: 7861 C$, p. 582 apud Comay, 2005, p. 56) de uma positividade "satânica" ( $B r$ 2: 7831 C, p. 579 apud Comay, 2005, p. 56).

As acusações já são conhecidas: Adorno o “diabo” (Lyotard), Adorno a "bruxa" (Agamben), Adorno o bêbado, ligado ao "misticismo da inversão dialética" (Bürger). Não é a invocação do "processo total" [Gesamtprozess] (Br 2:785/C, p.582 apud Comay, 2005, p. 56), para "desenvolvimento" (Durchführung) (Br 2: 7831/C, p. 580 apud Comay, 2005 , p. 56), para "mais dialética" - mais completa, na verdade talvez mais contínua dialética, durchdialektisieren - essa demanda por mediação não ameaça precisamente restabelecer uma continuidade historicista do tipo lukacsiano mais ortodoxo? Hegel contra Schelling? A demanda por elaboração teórica não ameaça reinvestir os "conteúdos da consciência" com as propriedades ocultas que devem ser especificamente evitadas? 
'Restauração da teologia' (pedido de Adorno) ( $B r 2:$ 6761/C, p. 498 apud Comay, 2005, p. 56), como muito mais ideologia alemã?

Mais ao ponto: a própria acusação da apologética não assume uma temporalidade linear do noch nicht? A acusação de reconciliação prematura não se arrogaria o próprio padrão de realização que, desse modo, recusaria? A própria alegação do positivismo não se acusaria essencialmente ao apelar ao proscrito ponto de vista da totalidade?

As coisas são complicadas. É de fato possível argumentar (como Benjamin quase faz) que a própria versão de "teoria" de Adorno - seja como a redenção esotérica dos fenômenos [Ideologiekritik] ou como o pontapé inicial de um Münchhausen filosófico - assume o ponto de vista angélico ou "asas enceradas" (GB 6: 184/C, p. 587 apud Comay, 2005, p. 57) do observador destacado. Se há, por certo, algum conceito de vanguarda nos 'espinhos' de Adorno ( $B r$ 2: 683/C, p. 503 apud Comay, 2005 , p. 57) (mais claramente assinalados em sua resposta ao ensaio sobre arte), o próprio Adorno é o primeiro a insistir que preço do sucesso teórico não seria apenas um fracasso prático, mas, de fato, um ponto cego teórico baseado precisamente na repressão dessa culpa original.

Se há uma estupidez intencional aqui - Adorno teimosamente confunde a imagem do sonho com a imagem dialética, convidando assim todas as inevitáveis refutações e réplicas - a má interpretação é reveladora na medida em que aponta para uma antinomia específica ainda não adequadamente abordada.

Pode ser que as suspeitas de Adorno, no final, e apesar de tudo, mantenham uma certa conviç̧ão. Talvez tanto Benjamin quanto Adorno compartilhem uma certa fantasia de reconciliação prematura. Talvez tal fantasia seja necessária. Suspenso entre o "deserto" do século XIX (J 33,2 apud Comay, 2005, p. 57) e o "deserto de gelo da abstração" (Adorno, 1974, p. 571), a luta entre Moisés e Arão pareceria insuportavelmente longa.

Será que o comprometimento de Benjamin com a fragmentação da totalidade inevitavelmente a restabelecerá em um nível mais alto? Se há alguma coisa que se assemelhe ao historicismo na indiscriminação da montagem, isto se dá precisamente na medida em que se arriscaria a adotar a perspectiva divina - o 'igual valor' do unmittelbar zu Gott de Leopold von Ranke, a "visão miraculosa" de Herman Lotze - da qual apenas a redenção no sentido estrito deve ser considerada (Cf. Kittsteiner, 1986, p. 179-215). Rettung aqui se confunde com Erlosung? 
Se a determinação de não ceder em nada é, como o próprio Benjamin admite, "verdadeiramente problemática" (N3,3 apud Comay, 2005, p. 57), isso talvez não seja automaticamente devido a um simples empirismo ou intuicionismo, mas sim (o que pode, no entanto, no fim, não ser tão diferente) à arrogância secreta que anteciparia a perspectiva de uma memória acessível exclusivamente a Deus (cf. GS 4.1:10/SW 1: 254 apud Comay, 2005, p. 57). A pilha ou agregado de imagens estrutura-se pelo ideal regulador da totalidade?

Se, 'para ter certeza' [freilich] - concessão estranha - 'é apenas para uma humanidade redimida que o passado se torna citável em todos e em cada um dos seus instantes (in jeder ihrer Momente: admitidamente, não "tudo" mas "cada e todos" em sua singularidade) (GS 1.2: 694 / SW 4:390 apud Comay, 2005, p. 57), o historiador aqui se transforma no cronista que assumiria a própria reconciliação que, por esse mesmo sinal, seria anulada? O "fraco poder messiânico" clama secretamente uma onipotência que subverteria até mesmo uma intervenção parcial no passado? Seja qual for a distinção entre a consoladora história universal do historicismo e o "esperanto" próprio do Messiânico (GS 1.3: 1239 apud Comay, 2005, p. 58), o materialista histórico não arrisca ambos, e precisamente na mesma medida, tendo em vista que ele sub-repticiamente ocluiria e, desse modo, hipostatizaria as condições presentes tanto do pensamento quanto do ato? Se "cada segundo" se tornar "o portão estreito através do qual o Messias poderia entrar" (GS 1.2: 704/SW 4: 397 apud Comay, 2005, p. 58) - sim, "o" Messias - como isso é diferente da abstração homogeneizante que apagaria a singularidade absoluta do evento revolucionário? O salto para o "ar livre" da história (GS 1.2:701/SW 4:395 apud Comay, 2005, p. 58) inevitavelmente reforça o próprio confinamento que ele contornaria? Negatividade abstrata como o positivismo secreto do dia? (Cf. Tiedemann, 1989, p. 201).

Se fazer tal acusação (como Adorno supostamente poderia ter feito) é, por si só, arriscar ser alvo de um historicismo complacente - acusar a reconciliação prematura é em si mesma assumi-la, e assim por diante - isso por si só indica o inextrincável entrelaçamento de duas "metades rasgadas de uma liberdade" (como o próprio Adorno caracterizava o impasse em outro contexto), a qual "elas, no entanto, não batem" (GS 1.3: 1003 apud Comay, 2005, p. 58). Adorno é igualmente culpado dessa negatividade abstrata que inevitavelmente (Hegel) abraçaria o presente na requintada gratificação de seu próprio desespero? É este então o 
interminável impasse entre a bela alma e seu impacientemente ingênuo adversário?

Talvez não seja uma questão de decisão aqui. No entanto, alguém há de (des)construir os termos da Auseinandersetzung - arte autônoma versus cultura de massa, conceito versus intuição, transcendência versus imanência, conscientização versus crítica redentora, socialismo cientifico versus socialismo utópico, racionalismo versus romantismo, Moisés versus Arão, Jeremias versus Ezequiel (as oposições não são desconexas, mas de modo algum idênticas) - a própria persistência da antinomia em si mesma aponta para algo insolúvel para o pensamento.

Quaisquer que sejam as diferenças, no final, entre a dialética negativa e a dialética paralisada, o entrelaçamento em si aponta para uma antinomia permanente ante o pensamento. Se Adorno e Benjamin inevitavelmente transgridem o Bilderverbot em seus esforços mais extenuantes para honrá-lo, isso por si só aponta para uma impaciência fundada na não-sincronicidade radical de toda vez. A lógica da latência não poderia significar nada além do empreendimento arriscado de uma imagem que não pode deixar de chegar 'cedo demais', mas igualmente "tarde demais". Há nesse sentido sempre um pouco de Fourier misturado em toda imaginação. Pode ser que, por essa razão (como Franz Rosenzweig teria insistido (Rosenzweig, 1961, p. 350)), esse falso messianismo inevitavelmente venha a definir não apenas o obstáculo, mas também a própria possibilidade de redenção. Disparar nas torres do relógio (cf. GS 1.2: 702/SW4: 395 apud Comay, 2005, p. 58) quebraria, no mínimo, qualquer ilusão de que a redenção ou a sua imagem poderiam vir na hora. Isso também deveria impedir qualquer ontologização fácil da questão, que apagaria a urgência específica de um imperativo, tanto mais urgente quanto a aparecer inevitavelmente tarde demais.

Seria, a esta luz, tentador, mas quase insuficiente concluir aqui, quando Adorno termina Minima Moralia, com a observação de que "além da demanda assim colocada no pensamento, a questão da realidade ou da irrealidade da redenção em si pouco importa". (Adorno, 1974, sec. 153).

\section{Rebecca Comay adotou as seguintes abreviações:}


AP The Arcades Project, trans. Howard Eiland and Kevin McLaughlin (Cambridge, MA: Belknap, 1999).

C The Correspondence of Walter Benjamin 1910 - 1940, ed. Gershom Scholem and Theodor W. Adorno, trans. Manfred R. Jakobson and Evelyn M. Jakobson (Chicago, IL: The University of Chicago Press, 1994).

CC Theodor W. Adorno and Walter Benjamin, The Complete Correspondence 1920-1940, ed. Henri Lonitz, trans. Nicholas Walker (Cambridge, MA: Harvard University Press, 1999).

$\boldsymbol{G B}$ Gesammelte Briefe, ed. Christoph Gb'dde and Henri Lonitz (Frankfurt am Main: Suhrkamp, 1995 and followingyears).

GS Walter Benjamin: Gesammelte Schriften, eds. Rolf Tiedemann and Hermann Schweppenhauser (Frankfurt am Main: Suhrkamp, 1974ff).

OT The Origin of the German Tragic Drama, trans. John Osborne (London: Verso, 1998).

SW Walter Benjamin, Selected Writings, ed. Michael W . Jennings (Cambridge, MA: Belknap, 1997-2003).

\section{Referências}

ABBA, R. H.f Rabbi Notes 253, 1935.

ADORNO, T. Kierkegaard: Construction of the Aesthetic. Minneapolis: University of Minnesota Press, 1989.

ADORNO, T. Quasi una fantasia. London: Verso, 1992.

ADORNO, T. Negative Dialektik. Frankfurt: Surkamp, 1966.

ADORNO, T. Negative Dialectics. Trad. Ashton, E. B. New York: Continuum, 1973.

ADORNO, T. Prismen. Frankfurt: Suhrkamp, 1955.

ADORNO, T. Prisms. Trad. Weber, S. and Weber, S. Cambrige: MIT, 1981.

ADORNO, T. Noten zur Literatur. Frankfurt: Suhrkamp, 1974. 
ADORNO, T. Notes to Literature. Trad. Nicholson, S. W. New York: Columbia University Press, 1972. v. 2.

ADORNO, T. Minima Moralia: Reflections from Damaged Life. Trad. Jephcott, E. F. N. London: NLB, 1974.

AGAMBEN, G. Le prince et le crapaud. In: Enfance et histoire: Deperissement de I'experience et origine de I'histoire, Paris: Payot, 1978. ARAGON, L. Paris Peasant. London: Cape, 1971.

BARTHES, R. Camera Lucida: Reflections on Photography. New York: Hill and Wang, 1981.

BAUDELAIRE, C. Salon de 1859. In: Ovres completes. Paris: Gallimard, 1979.

BLANCHOT, M. Interruptions. In: GOULD, Eric (org.). The Sin of the Book: Edmond Jabes. Lincoln: University of Nebraska Press, 1985.

BUCI-GLUCKSMANN, C. La folie du voir: de l'esthetique baroque. Paris: Galilee, 1986.

BUCK-MORSS, S. The Dialectics of Seeing: Walter Benjamin and the Arcades Project. Cambridge, Mass.: MIT, 1989.

BÜRGER, P. The decline of Modernism. University Park: Pennsylvania State University Press, 1992.

BYNUM, C. W. The Resurrection of the Body. New York: Columbia University Press, 1995.

BABYLONIAN TALMUD. Sanhedrin 91a-91b. Trad. I. Epstein. London: Soncino Pressin.

COHEN, H. Religion der Vernunft aus den Quellen des Judentums. Wiesbaden: Fourier Verlag, 1928. [reprint 1988].

COHEN, S. J. D. From the Maccabees to the Mishnah. Philadelphia: Westminster, 1987.

COMAY, R. Framing Redemption: Aura, Origin, Technology in Heidegger and Benjamin. In: DALLERY, A.; SCOTT, C. (org.). Ethics and Danger. Albany: Suny, 1992 
COMAY, R. Facies Hippocratica. In: PEPERZAK, A. (org.) Ethics as First Philosophy: The Thought of Emmanuel Levinas. New York: Routledge, 1995.

DALLERY, Arleen; SCOTT, Charles (ed.). Ethics and Danger. Albany: SUNY, 1992.

DALLERY, Arleen; SCOTT, Charles (ed.). Ethics as First Philosophy: The Thought of Emmanuel Levinas. New York: Routledge, 1995.

DEMETZ, P. (ed.) Theological-Political Fragment. Trad. Edmund Jephcott. In: Reflections: Essays, Aphorisms, Autobiographical Writings, New York: Harcourt Brace Jovanovich.

DERRIDA, J. Spectres of Marx. New York: Routledge, 1994.

FREUD, S. Interpretation of Dreams. Standard Edition of the Complete Works of Sigmund Freud. London: Hogarth Press, 1953.

FULD, W. Walter Benjamin: Zwischen den Stiihlen. Munich: Hanser Verlag, 1979.

HABERMAS, J. Walter Benjamin: Consciousness-Raising or Rescuing Critique. In: SMITH, Gary (org.). On Walter Benjamin: Critical Essays and Reflections. Cambridge, Mass.: MIT, 1988.

HEGEL, G. W. F. Phenomenology of Spirit. Oxford: Oxford University Press, 1977.

HEGEL, G. W. F. Grundlinien der Philosophie des Rechts. Frankfurt: Suhrkamp, 1970.

HEGEL, G. W. F. Aesthetics. Oxford: Oxford University Press, 1975. 2 v. HORKHEIMER, M.; ADORNO, T. Dialektik der Aufklarung. Frankfurt: Suhrkamp, 1984

HORKHEIMER, M.; ADORNO, T. Dialectic of Enlightenment. New York: Continuum, 1972.

IVORNEL, P. Paris, Capital of the Popular Front or the Posthumous Life of the 19th Century. New German Critique, v. 39, p. 61-84, 1986.

KANT, I. Critique of Judgment. New York: Hafner, 1951. 
KANT, I. Critique of Practical Reason. Indianapolis: Bobbs Merrill, 1956.

KORSCH, K. Karl Marx. Frankfurt am Main: Europaische Verlagsanstalt, 1967.

LACAN, J. The gaze as objet a. In: Four Fundamental Concepts of Psychoanalysis. New York: Norton, 1978.

LEVINAS, E. Totality and Infinity. Pittsburgh: Duquesne University Press, 1969.

LEVINAS, E. Difficult Freedom: Essays on Judaism. Chicago: University of Chicago Press, 1994.

LYOTARD, J-F. Adorno as the Devil. Telos, v. 19, p. 127-138, 1974.

MARX, K. "Afterword" to the second German edition of Capital. Moscow: Progress Publishers, 1959.

MARX, K.; ENGELS, F. Selected Correspondence 1846-95. New York: International Publishers, 1942.

MARX, K.; ENGELS, F. Werke. Berlin: Dietz, 1962.

MOORE, G. F. Judaism in the First Centuries of the Christian Era: The Age of Tannaim. Cambridge: Harvard University Press, 1927. [reprinted 1966]

NICKELSBURG, G. W. E. Resurrection, Immortality, and Eternal Life in Intertestamental Judaism. Cambridge: Harvard University Press, 1972.

NIETZSCHE, F. Will to Power, §603.

NIETZSCHE, F. Thus Spoke Zarathustra. New York: Viking, 1968.

PELIKAN, J. Christianity and Classical Culture: The Metamorphosis of Natural Theology in the Christian Encounter with Hellenism. New Haven: Yale University Press, 1993.

PELIKAN, J. The Christian Tradition: A History of the Development of Doctrine. Chicago: University of Chicago Press, 1971-1989. 5 v.

PROUST, M. Remembrance of Things Past. London: Penguin, 1983.

SCHOLEM, G. The Correspondence of Walter Benjamin and Gershom Scholem. New York: Schocken, 1989. 
SCHOLEM, G. Walter Benjamin: The Story of a Friendship. London: Faber and Faber, 1981.

SCHIVELBUSCH, W. Disenchanted Night: The Industrialization of Light in the Nineteenth Century. Berkeley: Unversity of California Press, 1988.

TAYLOR, R. Aesthetics and Politics. London: Verso, 1977.

TIEDEMANN, R. Historical Materialism or Political Messianism. In: SMITH, Gary (ed.). Walter Benjamin: Philosophy, History, Aesthetics. Chicago: University of Chicago Press, 1989.

WOHLFARTH, I. Resentment Begins at Home: Nietzsche, Benjamin, and the University. In: SMITH, Gary (ed.). Walter Benjamin: Philosophy, History, Aesthetics. Chicago: University of Chicago Press, 1989.

WOHLFARTH, I. Et Cetera? The Historian as Chiffonier. New German Critique, v. 39, 1985.

ROSENZWEIG, F. The True and the False Messiah: A Note to a Poem by Judah he-Levi. In: GLATZER, Nahum N. Franz Rosenzweig: His Life and Thought. New York: Schocken, 1961.

\section{Referências de citações da tradução}

ADORNO, T. Dialética Negativa. Trad. Casanova, M. A. Rio de Janeiro: Zahar, 2009.

ADORNO, T. Prismas. Trad. Wernet, A. e Almeida, J. M. B. São Paulo: Ática, 1998.

BENJAMIN, W. Rua de Mão Única”. Trad. Torres Filho, R. In: BENJAMIN, W. Obras escolhidas II. São Paulo: Brasiliense, 1997.

Recebido em: 23 de março de 2019 Aprovado em: 9 de maio de 2019 